Vol. 2. No. 2 Juli 2013

\title{
HUBUNGAN GAYA BELAJAR DAN MOTIVASI BELAJAR DENGAN HASIL BELAJAR KEWIRAUSAHAAN KELAS XI DI SMK NEGERI 1 BOGOR
}

\author{
Donna Rhamdan \\ Universitas Ibn Khaldun Bogor \\ Jl. K.H. Sohleh Iskandar Km. 2 Kedung Badak, Tanah Sareal Bogor \\ (donna.rhamdan@yahoo.com)
}

\begin{abstract}
Abstrak: Penelitian ini bertujuan untuk menguji hubungan gaya belajar dan motivasi belajar dengan hasil belajar kewirausahaan Kelas XI Akuntansi di SMK Negeri 1 Bogor. Masalah dalam penelitian ini adalah: hasil belajar kewirausahaan siswa kelas XI di SMK Negeri 1 Bogor belum mencapai kompetensi yang optimal. Penelitian dibatasi hanya tiga variabel yang akan diteliti antara lain: sebagai variabel bebas penelitian yaitu Gaya Belajar $\left(X_{1}\right)$, Motivasi Belajar $\left(X_{2}\right)$ dan variabel terikat yaitu Hasil Belajar Kewirausahaan (Y). Adapun perumusan masalah sebagai berikut: Apakah ada hubungan secara bersama-sama antara Gaya Belajar dan Motivasi Belajar dengan Hasil Belajar Siswa pada mata pelajaran Kewirausahaan Kelas XI di SMK Negeri 1 Bogor?. Metode yang digunakan dalam penelitian ini adalah metode kuantitatif menggunakan alat ukur yang kredibel dan validitas datanya bisa dipertanggungjawabkan. Dalam analisisnya menggunakan statistik atau pendekatan menggunakan angka dan skala ukur yang telah ditentukan. Metode ini digunakan untuk mengumpulkan data dari siswa kelas XI di SMK Negeri 1 Bogor berjumlah 480 siswa. Peneliti menggunakan teknik pengambilan data dengan Simple Random Sampling. Dengan demikian, karena sampel yang diambil relatif homogen yaitu Siswa Kelas XI di SMK Negeri 1 Bogor, cara pengambilan data yaitu $30 \%$ dari jumlah populasi yang berjumlah 480 siswa $(30 \% \times 480=144)$. Maka peneliti mengambil sampel berjumlah 144 orang dijadikan responden. Dari hasil penelitian yang telah dilaksanakan diperoleh data-data sebagai berikut: Berdasarkan hasil analisis rata-rata hitung (mean) gaya belajar 121,36 dan motivasi belajar 125,99 dengan hasil belajar rata-rata hitung (mean) sebesar 71,04. Hal ini menunjukkan bahwa jawaban responden dalam kategori kuat. Hasil menggambarkan nilai hubungan gaya belajar dan motivasi belajar dengan hasil belajar dengan angka (square) $r^{2}=$ 0,736 atau sebesar 73,6\%, angka menunjukkan bahwa hubungan variabel gaya belajar dan motivasi belajar dengan hasil belajar dinyatakan kuat, sisanya 26,4\% (100-73,6\% = 26,4\%) dipengaruhi hubungan keeratannya variabel lain. Diketahui terdapat hubungan yang signifikan Gaya Belajar dan Motivasi Belajar dengan Hasil Belajar Kewirausahaan Kelas XI Akuntansi di SMK Negeri 1 Bogor. Berdasarkan perhitungan terlihat angka hubungan gaya belajar dan motivasi belajar sebesar 0,592 menunjukkan hubungan cukup kuat dan positif. Untuk menganalisa keeratan hubungan antara variabel penyebab dilakukan dengan membandingkan $r_{\text {tabel }}$ terhadap $r_{\text {hitung maka didapat } n=144}$ didapat $t_{\text {tabel }}$ 1,976 dan $r_{\text {hitung }}$ 0,592 maka dinyatakan gaya belajar dan motivasi belajar ada hubungan yang cukup kuat. Kesimpulan:

1. Secara parsial ada hubungan kuat antara gaya belajar dengan hasil belajar sebesar $0,692(69,2 \%)$

2. Secara parsial ada hubungan kuat antara motivasi belajar dengan hasil belajar sebesar 0,604 $(60,4 \%)$

3. Secara bersama-sama nilai angka $r^{2}$ (square) 0,736 atau $73,6 \%$ selebihnya dipengaruhi variabel lain yang tidak dianalisis. Kompensasi terhadap hasil belajar sebagai berikut dengan nilai hubungannya 0,592 maka dinyatakan ada hubung erat antara gaya belajar dan motivasi belajar. Karena itu $\mathrm{H}_{0}$ ditolak dan $\mathrm{H}_{1}$ diterima.
\end{abstract}

Kata Kunci: gaya belajar, motivasi belajar, hasil belajar.

Abstract : This study aimed to examine the relationships learning styles and motivation for learning outcomes enterprise Class XI Accountancy in SMK Negeri 1 Bogor. The problem in this study are: the results of class XI students studying entrepreneurship at SMK Negeri 1 Bogor has not reached 
optimum competence. The study was confined only three variables that will be examined include: the independent variables, namely the study of Learning Styles $\left(X_{1}\right)$, Motivation $\left(X_{2}\right)$ and the dependent variable is the Entrepreneurship Learning Outcomes $(Y)$. The problem formulation as follows: Is there a relationship together between Learning Styles and Motivation for Student Results on Entrepreneurship subjects in Class XI SMK Negeri 1 Bogor?. The method used in this study is a quantitative method using measuring instruments credible and validity of the data can be accounted for. In his analysis using statistical or approach to use numbers and scale of measurement has been determined. This method is used to collect data from the students of class XI in SMK Negeri 1 Bogor totaled 480 students. Researchers used data collection techniques with Simple Random Sampling. Thus, because of a relatively homogeneous sample taken Class XI in which students of SMK Negeri 1 Bogor, how to capture the data that is $30 \%$ of the total population of 480 students ( $30 \%$ x $480=144$ ). Then the researchers took samples totaling 144 people as respondents. From the research that has been undertaken obtained the following data: Based on the analysis of the arithmetic mean (mean) learning styles and learning motivation 125,99 121,36 on learning outcomes arithmetic average (mean) of 71.04. This shows that respondents in the strong category. Results illustrate the value of the relationship of learning styles and learning motivation on learning outcomes with numbers (square) of $r^{2}=0,736$ or $73,6 \%$, figures show that the relationship variable learning styles and motivation toward learning outcomes expressed strong, the remaining 26,4\% (100-73,6\%=26,4\%) influenced the relationship keeratannya other variables. Known to have a significant relationship Learning Styles and Motivation for Learning Outcomes Enterprise Class XI Accountancy at SMK Negeri 1 Bogor. Based on the calculation of the numbers visible relationship of learning styles and learning motivation of 0,592 indicates fairly strong and positive relationships. To analyze the relationship between variables is done by comparing $r$ causes the table to the importance of the count $r n=144$ obtained $t_{\text {table }} 1,976$ and $r 0.592$ arthmetic count then stated learning style and motivation to learn there is a fairly strong relationship. conclusion:

1. Partially, there is a strong relationship between learning style on learning outcomes for $0,692(69,2$ $\%)$

2. Partially there is a strong relationship between learning motivation on learning outcomes 0,604 (60,4\%)

3. Taken together the numerical values $r^{2}$ (square) 0,736 or $73,6 \%$ remaining affected other variables not analyzed. Compensation for the following learning outcomes with the stated value of 0,592 conjunction no close relationship between learning styles and learning motivation. Therefore $H_{0}$ is rejected and $H_{1}$ is accepted.

Keyword: learning style, learning motivation, learning outcomes.

\section{PENDAHULUAN}

\subsection{Latar Belakang}

Pendidikan merupakan sarana untuk memperoleh ilmu agar dapat membentuk siswa yang berkarakter, sehingga mempunyai pandangan ke depan untuk meraih cita-cita dan dan mampu berdapatasi di lingkungan. Pendidikan dapat memotivasi siswa untuk lebih baik di segala aspek kehidupan. Di dunia pendidikan masih mempunyai kendala untuk mewujudkan pendidikan yang lebih baik, pendidikan yang berkarkter dan mampu mewujudkan pendidikan yang maju.

Pendidikan merupakan sebuah persoalan penting bagi kemajuan suatu bangsa. Dalam hal ini di sekolah tempat terjadinya proses pembelajaran yang diusahakan dengan sengaja untuk mengembangkan kepribadian dan segenap potensi siswa, sehingga dapat tumbuh dan berkembang sesuai dengan tujuan pendidikan nasional.

Belajar merupakan proses perubahan tingkah laku akibat dari interaksi dengan lingkungannya. Perubahan tersebut menyangkut perubahan pengetahuan, keterampilan, maupun sikap. Dalam pelaksanaan pendidikan terdapat beberapa faktor yang mempengaruhi gaya belajar yang harus dicermati oleh setiap pendidik, baik orang tua di rumah ataupun guru di sekolah. 
Di antara faktor-faktor yang mempengaruhi gaya belajar salah satunya adanya pengawasan yaitu bagaimana orang tua melakukan kontak keseharian atau komunikasi dengan putra-putrinya.

Di sekolah tak semua siswa punya gaya belajar yang sama. Termasuk apabila siswa bersekolah di sekolah yang sama atau bahkan duduk di kelas yang sama. Kemampuan siswa untuk memahami dan menyerap pelajaran berbeda tingkatnya. Ada yang cepat, sedang, dan ada pula yang sangat lambat. Oleh karena itu, siswa seringkali harus menempuh cara berbeda untuk bisa memahami sebuah informasi atau pelajaran yang sama. Apa pun cara yang dipilih, perbedaan gaya belajar menunjukkan cara tercepat dan terbaik bagi siswa untuk bisa menyerap materi pelajaran dan mendapatkan hasil belajar yang optimal.

Beberapa faktor yang mempengaruhi gaya belajar, secara garis besar merupakan upaya penanaman bukan pengajaran, dan akan menjadikan siswa menjadi lebih baik, terlebih jika masalah gaya belajar yang selama ini dikeluhkan dan ditanggulangi melalui gerakan terpadu antara orang tua, wali kelas, Guru mata pelajaran, Guru BK dan masyarakat.

Selanjutnya ada beberapa faktor yang mempengaruhi motivasi belajar antara lain: (1) Faktor Eksternal yaitu faktor dari luar individu yang terbagi menjadi dua yaitu faktor sosial meliputi faktor manusia lain, baik hadir secara langsung atau tidak langsung, dimana orang tua, guru mata pelajaran, guru BK, wali kelas, dan masyarakat yang dapat mempengaruhi motivasi belajar siswa di sekolah dan faktor non sosial meliputi keadaan udara, suhu udara, cuaca, waktu, tempat belajar, dan lainlain. (2) Faktor Internal yaitu faktor dari dalam diri individu yang terbagi menjadi dua yaitu faktor fisiologis meliputi keadaan jasmani dan keadaan fungsi-fungsi fisiologis dan faktor psikologis meliputi minat, kecerdasan, dan persepsi.

Setiap siswa memang tidak ada yang sama, perbedaan individual inilah yang menyebabkan perbedaan gaya belajar dan motivasi belajar dikalangan siswa, sehingga menyebabkan perbedaan hasil belajar. Hasil belajar merupakan hasil dari suatu proses yang di dalamnya terdapat sejumlah faktorfaktor saling mempengaruhi hasil belajar siswa.

Hasil belajar dapat dikatakan membekas atau konstan, jika perubahan yang terjadi akibat proses belajar tahan lama dan tidak mudah terhapus begitu saja. Dengan keadaan perbedaan gaya belajar dan rendahnya motivasi belajar siswa dapat mengakibatkan pencapaian hasil belajar siswa pun menjadi tidak optimal.

Teknologi Pendidikan merupakan spesialisasi lanjut dari ilmu pendidikan dalam mengatasi masalah belajar siswa. Salah satu masalah belajar yang dialami yaitu masih belum optimalnya hasil belajar. Teknologi pendidikan memanfaatkan berbagai macam sumber belajar dan media belajar dalam usaha pemecahan masalah belajar.

Teknologi pendidikan berusaha mengidentifikasi hal-hal yang belum terpecahkan, dan mencari cara-cara baru yang inovatif sesuai dengan perkembangan budaya dan hasrat manusia untuk memperbaiki dirinya. Dimana faktor yang menjadi penyebab belum optimalnya hasil belajar yaitu perbedaan gaya belajar dan motivasi belajar.

Diduga permasalahan yang dihadapi Siswa Kelas XI di SMK Negeri 1 Bogor yaitu hasil belajar kewirausahaan belum optimal, karena faktor-faktor gaya belajar dan motivasi belajar. Berdasarkan uraian di atas, maka penulis tertarik untuk melakukan penelitian dengan judul "Hubungan Gaya Belajar dan Motivasi Belajar dengan Hasil Belajar Kewirausahaan Kelas XI di SMK Negeri 1 Bogor".

\subsection{Rumusan Masalah}

Adapun perumusan masalah yang dapat dilakukan sebagai berikut: Apakah ada hubungan secara bersama-sama antara Gaya Belajar dan Motivasi Belajar dengan Hasil Belajar Siswa pada mata pelajaran Kewirausahaan Kelas XI di SMK Negeri 1 Bogor? 


\subsection{Tujuan Penelitian}

Penelitian ini dilakukan untuk mendapatkan data dan informasi yang relevan mengenai hubungan Gaya Belajar dan Motivasi Belajar dengan Hasil Belajar Kewirausahaan Kelas XI di SMK Negeri 1 Bogor. untuk mengetahui: Gaya Belajar di SMK Negeri 1 Bogor. Motivasi Belajar di SMK Negeri 1 Bogor. Hasil Belajar Kewirausahaan Kelas XI di SMK Negeri 1 Bogor. Hubungan Gaya Belajar dan Motivasi Belajar dengan Hasil Belajar Kewirausahaan Kelas XI di SMK Negeri 1 Bogor.

\section{TINJAUAN TEORI}

\subsection{Kerangka Teoritik}

\subsubsection{Hakikat Hasil Belajar dan Pembelajaran Kewirausahaan}

Suyono dan Hariyanto (2011:9) mengemukakan bahwa: Belajar adalah suatu aktivitas atau suatu proses untuk memperoleh pengetahuan, meningkatkan keterampilan, memperbaiki perilaku, sikap, dan mengokohkan kepribadian. Dalam konteks menjadi tahu atau proses memperoleh pengetahuan, menurut pemahaman sains konvensional, kontak manusia dengan alam diistilahkan dengan pengalaman (experience). Pengalaman yang terjadi berulang kali melahirkan pengetahuan (knowledge), atau a body of knowledge.

Definisi di atas merupakan definisi umum dalam pembelajaran sains secara konvensional, dan beranggapan bahwa pengetahuan sudah berada di alam, tinggal bagaimana siswa atau pembelajar bereksplorasi, menggali dan menemukan kemudian memungutnya, untuk memperoleh pengetahuan.

Sedangkan Dimyati dan Mudjiono (2006:7) mengemukakan bahwa: Belajar merupakan tindakan dan perilaku siswa yang kompleks. Sebagai tindakan, maka belajar hanya dialami oleh siswa sendiri. Siswa adalah penentu terjadinya atau tidak terjadinya proses belajar. Proses belajar terjadi berkat siswa memperoleh sesuatu yang ada di lingkungan sekitar. Lingkungan yang dipelajari oleh siswa berupa keadaan alam, bendabenda, hewan, tumbuh-tumbuhan, manusia, atau hal-hal yang dijadikan bahan belajar.
Tindakan belajar tentang suatu hal tersebut tampak sebagai perilaku belajar yang tampak dari luar.

Dari penjelasan di atas dapat disimpulkan bahwa belajar merupakan peristiwa sehari-hari. Belajar merupakan hal yang kompleks. Kompleksitas belajar dapat dipandang dari segi siswa, belajar dialami sebagai suatu proses. Siswa mengalami proses mental dalam menghadapi bahan belajar. Bahan belajar berupa keadaan alam, hewan, tumbuh-tumbuhan, manusia, dan bahan yang telah terhimpun dalam buku-buku pelajaran.

Suyono dan Hariyanto (2011:14) mengemukakan bahwa: Belajar membutuhkan keterlibatan mental dan aktivitas siswa sendiri. Artinya belajar baru bermakna jika ada pembelajaran terhadap dan oleh siswa.

Undang-Undang No. 20 Tahun 2003 Tentang Sistem Pendidikan Nasional pasal 1 ayat 20 menjelaskan bahwa: Pembelajaran adalah proses interaksi peserta didik dengan pendidik dan sumber belajar pada suatu lingkungan belajar. Sedangkan menurut Syaiful Sagala (2011:61) mengutip pendapat Corey mengemukakan bahwa: Konsep pembelajaran adalah suatu proses dimana lingkungan seseorang secara disengaja dikelola untuk memungkinkan ia turut serta dalam tingkah laku tertentu dalam kondisikondisi khusus atau menghasilkan respons terhadap situasi tertentu.

Selanjutnya Syaiful Sagala (2011:61) mengutip pendapat Dimyati dan Mudjiono mengemukakan bahwa pembelajaran adalah kegiatan guru secara terprogram dalam desain instruksional, untuk membuat belajar secara aktif, yang menekankan pada penyediaan sumber belajar.

Dari penjelasan di atas dapat disimpulkan bahwa pembelajaran adalah usaha sadar dari guru untuk membuat siswa belajar, yaitu terjadinya perubahan tingkah laku pada diri siswa yang belajar.

Hamzah B. Uno (2009:11) mengutip pendapat Thorndike, salah seorang pendiri aliran teori belajar tingkah laku, 
mengemukakan teorinya bahwa: "Belajar adalah proses interaksi antara stimulus (yang mungkin berupa pikiran, perasaan atau gerakan)." Jelasnya menurut Thorndike, perubahan tingkah laku dapat berwujud sesuatu yang konkret (dapat diamati), atau yang nonkonkret (tidak bisa diamati).

Hasil Belajar menurut Nana Syaodih Sukmadinata (2009:102-103) menyatakan bahwa: Hasil belajar atau achievement merupakan realisasi dari kecakapankecakapan potensial atau kapasitas yang dimiliki seseorang. Sedangkan menurut Nana Sudjana (2003:22) hasil belajar adalah kemampuan-kemampuan yang dimiliki siswa setelah ia menerima pengalamannya.

Syafaruddin dan Irwan Nasution (2005:141) mengemukakan bahwa: pembelajaran menekankan pencapaian tujuan baik berdimensi kognitif, afektif, maupun psikomotor sehingga pencapaian hasil belajar menjadi terpadu dari totalitas kepribadian peserta didik.

Pengukuran hasil belajar menurut Nana Syaodih Sukmadinata (2009:103) menyatakan bahwa: pada kecerdasan, hasil belajar dapat diukur. Alat untuk mengukur hasil belajar disebut tes hasil belajar. Tes hasil belajar kebanyakan disusun oleh guru. Untuk setiap mata pelajaran pada setiap semester atau caturwulan minimal dapat disusun satu tes hasil belajar.

Dari penjelasan di atas dapat diambil kesimpulan bahwa hasil belajar dapat diukur dengan cara memberikan tes hasil belajar. Tes hasil belajar dapat disusun minimal satu tes hasil belajar.

Tes dibuat seandal (reliable) mungkin, sehingga mudah diinterpretasikan dengan baik. Suatu alat evaluasi dikatakan andal jika dapat menghasilkan pengukuran yang benarbenar dapat dipercaya. Suatu tes dapat dikatakan andal jika tes itu dilakukan berulang-ulang terhadap objek yang sama, hasilnya akan tetap sama atau relatif sama.

Salah satu dari spesialisasi teknologi pendidikan yaitu mengatasi masalah belajar dan berusaha mengidentifikasi hal-hal yang belum jelas/belum terpecahkan. Dimana masalah belajar atau hasil belajar yang belum optimal dapat berasal dari berbagai faktor, beberapa diantaranya yaitu gaya belajar dan motivasi belajar siswa.

$$
\text { Yusufhadi Miarso }
$$
mengemukakan bahwa: "Teknologi pendidikan berusaha mengidentifikasi hal-hal yang belum jelas/belum terpecahkan, dan mencari cara baru yang inovatif sesuai dengan perkembangan budaya dan hasrat manusia untuk memperbaiki dirinya."

Sedangkan Steven Hackbarth (1996:11) mengemukakan bahwa: Definition of Educational Technology it is a systematic process involving application of knowledge in the search for replicable solutions to problems inherent in teaching and learning.

Dari definisi di atas dapat disimpulkan bahwa Teknologi Pendidikan adalah proses sistematis yang melibatkan penerapan pengetahuan dalam mencari solusi untuk masalah dalam proses belajar mengajar. Salah satu aplikasi teknologi pendidikan adalah memecahkan masalah belajar pada manusia secara menyeluruh dan serempak, dengan memerhatikan dan mengkaji semua kondisi dan saling kaitan diantaranya.

\subsubsection{Hakikat Gaya Belajar Kewirausahaan}

Gunawan (2006:139) mengemukakan bahwa gaya belajar adalah cara yang lebih disukai dalam melakukan kegiatan berfikir, memproses dan mengerti suatu informasi.

Sedangkan DePorter dan Hernacki (2007:110) mengemukakan bahwa: Gaya belajar adalah kombinasi dari menyerap, mengatur, dan mengolah informasi. Secara umum, gaya belajar dapat dikelompokkan berdasarkan kemudahan dalam menyerap informasi (perceptual modality), cara memproses informasi (information processing), dan karakteristik dasar kepribadian (personality pattern). Pengelompokan berdasarkan perceptual modality didasarkan pada reaksi individu terhadap lingkungan fisik dan cara individu menyerap data secara lebih efisien. Pengelompokan berdasarkan information processing didasarkan pada cara individu 
merasa, memikirkan, memecahkan masalah, dan mengingat informasi. Sedangkan pengelompokan berdasarkan personality pattern didasarkan pada perhatian, emosi, dan nilai-nilai yang dimiliki oleh individu.

M. Alisuf Sabri (2007:102) mengemukakan bahwa: Gaya belajar atau learning style ialah cara siswa bereaksi dan menggunakan perangsang-perangsang yang diterimanya dalam belajar atau proses belajar mengajar di sekolah.

Sedangkan Nasution (2008:93) gaya belajar atau "learning style" siswa yaitu cara siswa bereaksi dan menggunakan perangsang-perangsang yang diterimanya dalam proses belajar. Selanjutnya Winkel (2005:164) mengemukakan bahwa: Gaya belajar merupakan cara belajar yang khas bagi siswa.

Dari penjelasan di atas dapat disimpulkan bahwa gaya belajar merupakan kombinasi dari menyerap informasi, memproses informasi sampai dengan mengolah informasi. Gaya belajar merupakan ciri khas yang dimiliki oleh setiap siswa dalam memberikan respon atau reaksi terhadap pembelajaran yang diterimanya.

DePorter dan Hernacki (2007:112) mengemukakan terdapat tiga jenis gaya belajar berdasarkan modalitas yang digunakan individu dalam memproses informasi (perceptual modality). Ketiga gaya belajar tersebut adalah gaya belajar visual, auditorial, dan kinestetik.

Setiap guru harus mengenali gaya belajar siswanya, dan guru juga harus memiliki sikap seperti gaya belajar yang dimiliki setiap siswanya. Setiap siswa memiliki gaya belajar yang berbeda dan bisa belajar dengan lebih baik dengan cara yang berbeda-beda.

\subsubsection{Hakikat Motivasi Belajar Kewirausahaan}

Isbandi Rukminto Adi (2009:3) mengemukakan bahwa: Istilah motivasi berasal dari kata motif yang dapat diartikan sebagai kekuatan yang terdapat dalam diri individu, yang menyebabkan individu tersebut bertindak atau berbuat. Motif tidak dapat diamati secara langsung, tetapi dapat diinterprestasikan dalam tingkah lakunya, berupa rangsangan, dorongan, atau pembangkit tenaga munculnya suatu tingkah laku tertentu.

Selanjutnya Isbandi Thomas L. Good \& Jere E. Brophy dikutip langsung (atau tidak langsung) Rukminto Adi (2009:3-4) mengemukakan bahwa: Berkaitan dengan pengertian motivasi, beberapa psikolog menyebut motivasi sebagai konstruk hipotesis yang digunakan untuk menjelaskan keinginan, arah, intensitas, dan keajegan perilaku yang diarahkan oleh tujuan. Dalam motivasi tercakup konsep-konsep, seperti kebutuhan untuk berprestasi, kebutuhan berafiliasi, kebiasaan, dan keingintahuan seseorang terhadap sesuatu.

Sedangkan Mark K. Smith, et al., (2009:19) mengemukakan bahwa: motivasi adalah sebuah konsep utama dalam banyak teori pembelajaran. Motivasi sangatlah dikaitkan dengan dorongan, perhatian, kecemasan, dan umpan balik/penguatan.

\section{Aunurrahman}

(2009:180) mengemukakan bahwa: Motivasi Belajar adalah motivasi didalam kegiatan belajar merupakan kekuatan yang dapat menjadi tenaga pendorong bagi siswa untuk mendayagunakan potensi-potensi yang ada pada dirinya dan potensi di luar dirinya untuk mewujudkan tujuan belajar.

Selanjutnya Hamzah B. Uno (2009:23) mengemukakan bahwa: Hakikat motivasi belajar adalah dorongan internal dan eksternal pada siswa-siswa yang sedang belajar untuk mengadakan perubahan tingkah laku.

Dari penjelasan di atas dapat disimpulkan bahwa faktor motivasi belajar berpengaruh terhadap tindakan, hasrat dan keinginan berhasil siswa dalam belajar, sehingga mendapatkan hasil belajar yang baik.

Motivasi belajar kewirausahaan merupakan hasrat dan keinginan berhasil dan dorongan kebutuhan belajar kewirausahaan, harapan akan mendapatkan hasil belajar kewirausahaan yang optimal. Dan adanya 
penghargaan dari guru, lingkungan belajar kewirausahaan yang kondusif, dan kegiatan belajar kewirausahaan yang menarik. Tetapi harus diingat, kedua faktor tersebut disebabkan oleh rangsangan dari dalam diri siswa dan dari lingkungan belajar, sehingga siswa berkeinginan untuk melakukan aktivitas belajar kewirausahaan yang lebih semangat.

Motivasi belajar kewirausahaan yang meningkat dapat mengoptimalkan hasil belajar kewirausahaan. Jika semakin tinggi motivasi belajar kewirausahaan, maka dorongan untuk mendapatkan hasil belajar kewirausahaan akan semakin tinggi pula. Sebaliknya siswa yang kurang memiliki motivasi belajar kewirausahaan, umumnya kurang mampu bertahan untuk belajar lebih lama, kurang sungguh-sungguh dalam mengerjakan tugas kewirausahaan. Rendahnya motivasi belajar kewirausahaan merupakan masalah belajar, karena memberikan dampak bagi hasil belajar kewirausahaan yang diharapkan.

\subsection{Kerangka Berfikir}

Gaya belajar merupakan kombinasi dari menyerap, memproses, dan mengolah informasi. Gaya belajar dapat dikelompokkan berdasarkan kemudahan dalam menyerap informasi (perceptual modality), cara memproses informasi (information processing), dan karakteristik dasar kepribadian (personality pattern). Pengelompokan berdasarkan perceptual modality didasarkan pada reaksi individu terhadap lingkungan fisik dan cara individu menyerap data secara lebih efisien. Pengelompokan berdasarkan information processing didasarkan pada cara individu merasa, memikirkan, memecahkan masalah, dan mengingat informasi. Sedangkan pengelompokan berdasarkan personality pattern didasarkan pada perhatian, emosi, dan nilai-nilai yang dimiliki oleh individu.

Siswa yang memiliki motivasi belajar akan nampak melalui kesungguhan untuk terlibat di dalam proses pembelajaran, antara lain nampak melalui keaktifan bertanya, mengemukakan pendapat, menyimpulkan pelajaran, mencatat, membuat resume, mempraktekkan sesuatu, mengerjakan latihan dan evaluasi sesuai dengan tuntutan pembelajaran sehingga memperoleh hasil belajar yang optimal.

Penguasaan hasil belajar oleh seseorang dapat dilihat dari perilakunya, baik perilaku dalam bentuk penguasaan pengetahuan, keterampilan berpikir maupun keterampilan motorik. Hampir sebagian terbesar dari kegiatan atau perilaku yang diperlihatkan seseorang merupakan hasil belajar. Di sekolah hasil belajar ini dapat dilihat dari penguasaan siswa akan mata-mata pelajaran yang ditempuhnya.

Faktor gaya belajar dan motivasi belajar merupakan salah satu dari faktor-faktor yang dapat mempengaruhi hasil belajar siswa, jika gaya belajar dan motivasi belajar baik, maka hasil belajar siswa juga akan baik, maka peneliti menduga terdapat hubungan yang positif antara gaya belajar dan motivasi belajar terhadap hasil belajar siswa.

\subsection{Hipotesis Penelitian}

\subsubsection{Hipotesis Deskriptif}

Hipotesis merupakan dugaan sementara yang kebenarannya harus diuji secara empiris. Berdasarkan kerangka berpikir di atas, penulis mengemukakan hipotesis sebagai berikut:

$\mathrm{H}_{0}$ : Tidak terdapat hubungan gaya belajar dengan hasil belajar.

$\mathrm{H}_{1}$ : Terdapat hubungan gaya belajar dengan hasil belajar.

$\mathrm{H}_{0}$ : Tidak terdapat hubungan motivasi belajar dengan hasil belajar.

$\mathrm{H}_{1}$ : Terdapat hubungan motivasi belajar dengan hasil belajar.

$\mathrm{H}_{0}$ : Tidak terdapat hubungan gaya belajar dan motivasi belajar dengan hasil belajar.

$\mathrm{H}_{1}$ : Terdapat hubungan gaya belajar dan motivasi belajar dengan hasil belajar.

\subsubsection{Hipotesis Statistik}

Adapun Hipotesis Statistik sebagai berikut:

H0 : $\rho_{-}(y .1)=0$ tidak terdapat hubungan gaya belajar dengan hasil belajar.

H1 : $\rho_{-}(y .1)>0$ terdapat hubungan gaya belajar dengan hasil belajar. 


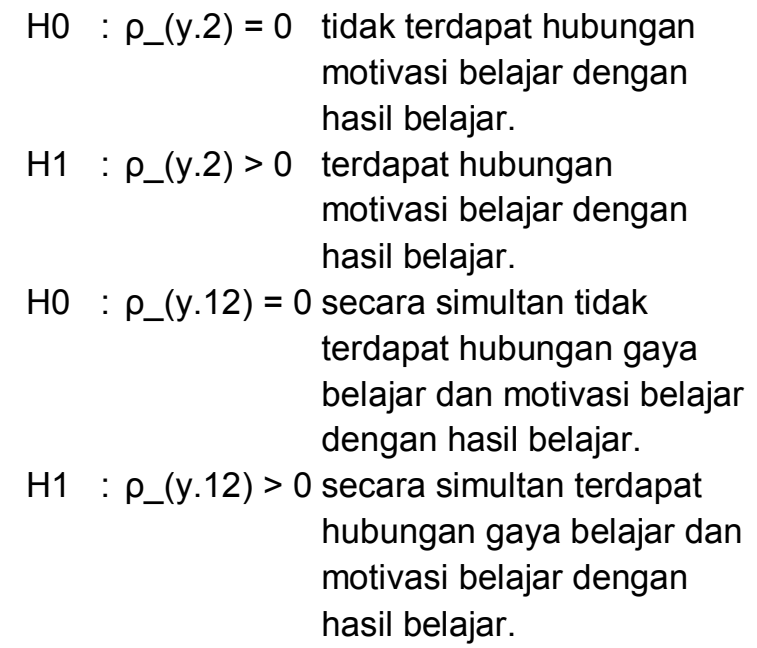

\section{METODOLOGI PENELITIAN}

\subsection{Waktu dan Tempat Penelitian}

Adapun tempat penelitian adalah di SMK Negeri 1 Bogor. Waktu penelitian di agendakan selama kurun waktu 4 bulan. Mulai dari minggu pertama bulan Juli sampai dengan Oktober 2013.

\subsection{Metode Penelitian}

Masyhudzulhak (2012:29) Metode yang digunakan dalam penelitian ini adalah metode kuantitatif menggunakan alat ukur yang kredibel dan validitas datanya bisa dipertanggungjawabkan. Dalam analisisnya menggunakan statistik atau pendekatan menggunakan angka dan skala ukur yang telah ditentukan.

Metode kuantitatif digunakan untuk mengumpulkan data dari siswa. Penelitian ini mengkaji hubungan tiga variabel, yaitu dua variabel bebas yaitu Gaya Belajar (X1), Motivasi Belajar (X2) dan satu variabel terikat yaitu Hasil Belajar (Y). Untuk kompilasi antar variabel digambarkan sebagai berikut:

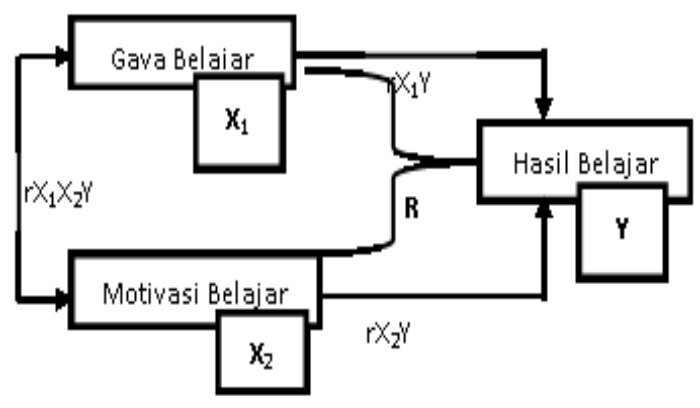

Gambar 1. Desain Variabel Penelitian

\subsection{Populasi dan Sampling}

Siswa Kelas XI di SMK Negeri 1 Bogor berjumlah 480 siswa. Peneliti menggunakan teknik pengambilan data dengan Simple Random Sampling yaitu cara pengambilan data (populasi) secara acak yaitu semua populasi dapat kesempatan sama tanpa memperhatikan stratanya dengan syarat jika sampelnya homogen atau relatif homogen.

Dengan demikian, karena sampel yang diambil relatif homogen yaitu Siswa Kelas XI di SMK Negeri 1 Bogor, cara pengambilan data yaitu $30 \%$ dari jumlah populasi yang berjumlah 480 siswa $(30 \%$ X $480=144)$. Maka peneliti mengambil sampel berjumlah 144 orang dijadikan responden.

\subsection{Instrumen Penelitian}

Peneliti membuat kisi-kisi penelitian dengan merinci dan menjabarkan variabel penelitian ke dalam dimensi penelitian dan selanjutnya indikator penelitian. Dirumuskan sejalan dengan tujuan maupun pertanyaan penelitian, kemudian dibuat beberapa pertanyaan untuk dijadikan angket/kuesioner. Pertanyaan dalam angket disusun secara singkat, jelas dan terarah, agar mudah dimengerti dan dapat mengungkap data dan informasi yang diperlukan dalam penelitian.

Instrumen yang digunakan untuk mengukur gaya belajar berbentuk kuesioner $\geq$ 30 butir pertanyaan, motivasi belajar $\geq 30$ butir pertanyaan, dan hasil $\geq$ belajar 30 butir soal. Responden instrumen ini adalah Siswa Kelas XI SMK Negeri 1 Bogor.

Untuk mengetahui apakah angket yang disusun dapat dipakai atau tidak oleh responden dan memenuhi unsur validitas atau tidak, diperlukan langkah uji coba terhadap angket yang disusun dengan cara membagikan angket kepada beberapa siswa yang memiliki karakteristik yang sama dengan populasi yang sebenarnya. Langkah dimaksudkan untuk mengecek dan mengevaluasi bahasa yang digunakan dalam angket yang disusun, baik menyangkut materi pertanyaan, maupun redaksi sehingga dapat diketahui kekurangan dan kelebihan dari keseluruhan isi angket yang telah dibuat. 
Uji reliabilitas adalah untuk mengukur kehandalan data yang telah didapat dengan model reliabilitas ini apakah jawaban responden tetap konsisten dan stabilitas nilai hasil skala dibuat dan kegunaannya untuk mengukur akurasi pengukuran hasilnya.

\subsection{Teknik Analisis Data}

Teknik analisis data diperlukan dalam menguji hipotesis yang diajukan agar diketahui hubungan antara Gaya Belajar dan Motivasi Belajar dengan Hasil Belajar.

Teknik analisis data yang akan dilakukan yaitu menyebarkan kuesioner terhadap responden, dan setelah kuesioner yang disebarkan terkumpul kembali, maka dilanjutkan dengan menganalisa secara kuantitatif melalui tiga tahap. Pertama, menganalisis data sebagai tahap pendahuluan. Kedua, tahap pengorganisasian data, tahap ini termasuk tahap inti yang dimulai dari 1) menghitung frekuensi, 2) tabulasi, 3) analisis data, penemuan ada dan tidaknya hubungan antara variabel, 4) mengukur derajat besaran hubungan antar variabel. Ketiga, yaitu tahap penemuan hasil yang merupakan kesimpulan pengukuran besarnya hubungan.

\section{HASIL DAN PEMBAHASAN}

\subsection{Data Hasil Penelitian}

\subsubsection{Data Gaya Belajar}

Data dianalisis dengan menggunakan SPSS Versi 20 (IBM) atau Statistic Product and Service Solution merupakan perangkat (software statistik) dalam memecahkan analisis statistik, alasan peneliti menggunakan SPSS Versi 20 (IBM) karena versi terbaru yang dikeluarkan IBM.

Selanjutnya data mengenai gaya belajar siswa kelas XI di SMK Negeri 1 Bogor. Kemudian data dianalisis dengan menggunakan SPSS 20 (IBM) atau Statistic Product and Service Solution merupakan perangkat (software statistik) dalam memecahkan analisis statistik. Data mengenai gaya belajar dapat diuraikan berdasarkan data berikut ini:

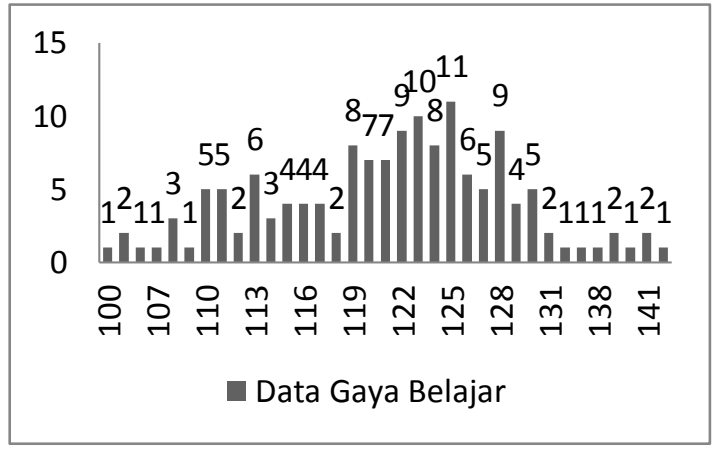

Gambar 2. Data Gaya Belajar $\left(\mathrm{X}_{1}\right)$

Berdasarkan data di atas, maka dapat dilihat bahwa gaya belajar siswa kelas $\mathrm{XI}$ di SMK Negeri 1 Bogor menunjukkan jumlah nilai angket tertinggi adalah 125 sebesar 11 dan terendah adalah $100,105,107,109,132,133$, 138, 140, dan 142 sebesar 1 .

Tabel 1. Data Gaya Belajar

\begin{tabular}{|l|c|}
\hline \multicolumn{2}{|c|}{ Data Gaya Belajar } \\
\hline Visual & 5833 \\
\hline Auditori & 5861 \\
\hline Kinestetik & 5782 \\
\hline
\end{tabular}

Berdasarkan data di atas, maka dapat dilihat bahwa gaya belajar siswa kelas XI di SMK Negeri 1 Bogor menunjukkan jumlah gaya belajar visual sebesar 5833 , auditori sebesar 5861, dan kinestetik 5782.

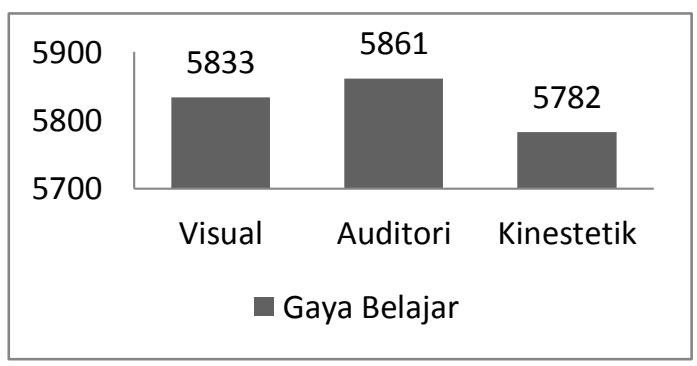

Gambar 3 Data Gaya Belajar $\left(\mathrm{X}_{1}\right)$

\subsubsection{Data Motivasi Belajar}

Data mengenai motivasi belajar siswa kelas XI di SMK Negeri 1 Bogor diambil dengan menggunakan kuesioner dengan cara memberikan daftar pertanyaan yang digunakan untuk menggali data mengenai motivasi belajar yang diberikan kepada responden. Data mengenai motivasi belajar dapat diuraikan berdasarkan data berikut ini: 


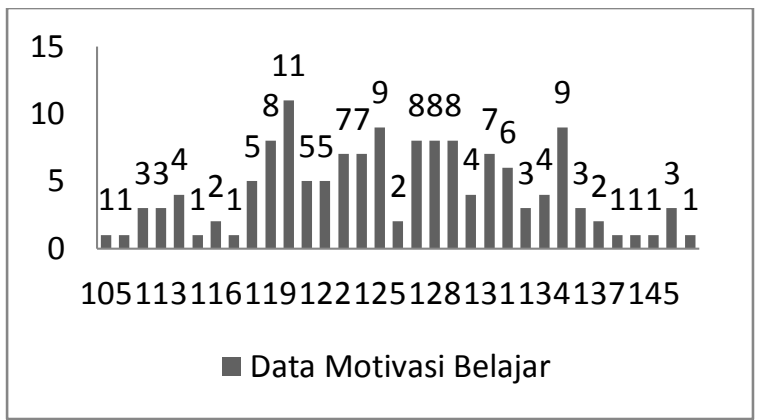

Gambar 4 Data Motivasi Belajar $\left(\mathrm{X}_{2}\right)$

Berdasarkan data di atas, maka dapat dilihat bahwa motivasi belajar siswa kelas XI di SMK Negeri 1 Bogor menunjukkan jumlah nilai angket tertinggi adalah 120 sebesar 11 dan terendah adalah 105, 110, 115, 117, 143, 144, 145, dan 147 sebesar 1. Rata-rata nilai motivasi belajar dihitung dengan rumus:

$R=\sum_{i=1}^{i=n} \frac{X i}{n}$

Keterangan:

$R=$ nilai rata-rata,

$n=$ banyaknya siswa,

$X_{i}=$ nilai masing-masing siswa, $i=1,2,3$, ..., 144

$R=\sum_{i=1}^{i=n} \frac{X i}{n}=\frac{18143}{144}=125.9930556=126$

Berdasarkan perhitungan data di atas, maka dapat dilihat bahwa rata-rata motivasi belajar siswa kelas XI di SMK Negeri 1 Bogor menunjukkan jumlah nilai 126. Di samping jumlah nilai angket di atas, untuk penarikan kesimpulan data angket motivasi belajar dilakukan klasifikasi hasil data angket motivasi belajar sesuai dengan tabel berikut:

Tabel 2. Klasifikasi Hasil Persentase Skor Motivasi Belajar

\begin{tabular}{|l|l|}
\hline Persentase skor yang diperoleh & Kategori \\
\hline $91 \% \leq X \leq 100 \%$ & Tinggi \\
\hline $81 \% \leq X \leq 90 \%$ & Sedang \\
\hline$\leq 80 \%$ & Rendah \\
\hline
\end{tabular}

Cara menghitung persentase hasil angket motivasi belajar:

$$
X=\left(\frac{A}{B}\right) \times 100 \%
$$

Keterangan:

$X=$ persentase total yang diperoleh,

$A=$ jumlah skor yang diperoleh siswa pada setiap variabel

$B=$ jumlah skor total maksimal pada setiap variabel/aspek.

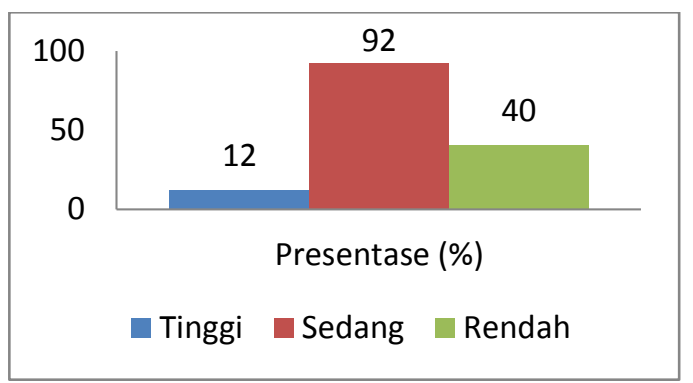

Gambar 5. Persentase (\%) Hasil Angket Motivasi Belajar $\left(\mathrm{X}_{2}\right)$

Berdasarkan data di atas, maka dapat dilihat bahwa presentase hasil angket motivasi belajar siswa kelas XI di SMK Negeri 1 Bogor menunjukkan presentase kategori tinggi (91\% $\leq X \leq 100 \%)$ dengan jumlah 12 , kategori sedang $(81 \% \leq X \leq 90 \%)$ dengan jumlah 92 dan rendah $(\leq 80 \%)$ dengan jumlah 40 .

\subsubsection{Data Hasil Belajar}

Data mengenai hasil belajar siswa kelas XI di SMK Negeri 1 Bogor diambil dengan menggunakan tes dengan cara memberikan soal yang digunakan untuk menggali data mengenai hasil belajar yang diberikan kepada responden. Data mengenai hasil belajar dapat diuraikan berdasarkan data berikut ini:

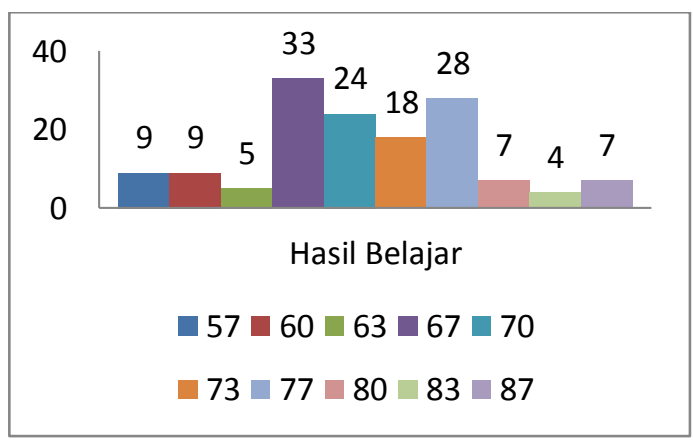

Gambar 6. Hasil Belajar Siswa Kelas XI

Berdasarkan diagram 4.5 di atas, maka dapat dilihat bahwa hasil belajar siswa kelas $\mathrm{XI}$ di SMK Negeri 1 Bogor, nilai tertinggi adalah 87 dan nilai terendah 57 . 


\subsection{Pengujian Persyaratan Analisis}

Analisis data dimaksudkan untuk melakukan pengujian hipotesis dan menjawab rumusan masalah yang diajukan, karena menggunakan skala interval dan rasio, maka sebelum melakukan pengujian harus dipenuhi persyaratan analisis terlebih dahulu, dengan asumsi bahwa data harus dipilih secara acak (random), homogen, normal, bersifat linier, dan berpasangan.

\subsubsection{Uji Homogenitas}

Uji homogenitas yang akan dipaparkan oleh peneliti dengan uji Barlet dan uji varians terbesar dibanding varian terkecil menggunakan Tabel $\mathrm{F}$.

Standar Deviasi X1 $=7,996$ maka Varians $=63,939$

Standar Deviasi X2 $=7,950$ maka Varians $=63,210$

Standar Deviasi $Y \quad=7,357$ maka Varians $=54,124$

Tabel 3. Nilai Varians Besar Dan Kecil

\begin{tabular}{|c|c|c|c|}
\hline Nilai Varians Sampel & \multicolumn{3}{|c|}{ Jenis Variabel: Hubungan } \\
\hline & Gaya Belajar & Motivasi Belajar & Hasil Belajar \\
\hline $\mathrm{S}^{2}$ & 63,939 & 63,210 & 54,124 \\
\hline $\mathrm{n}$ & 144 & 144 & 144 \\
\hline
\end{tabular}

Selanjutnya memasukkan angka-angka disusun tabel pada berikut ini: statistik untuk pengujian homogenitas

Tabel 4. Uji Bartlet

\begin{tabular}{|c|c|c|c|c|}
\hline Sampel & $\mathrm{db}=(\mathrm{n}-1)$ & $\overline{\mathrm{S}_{i}^{2}}$ & $\log S_{i}^{2}$ & $(\mathrm{db}) \log S_{i}^{2}$ \\
\hline $1=(\mathrm{X} 1)$ & 143 & 63,939 & 1,81 & 258,83 \\
\hline $2=(X 2)$ & 143 & 63,210 & 1,80 & 257,40 \\
\hline $3=(Y)$ & 143 & 54,124 & 1,73 & 247,39 \\
\hline Jumlah = 3 & $\sum(n i-1)=429$ & - & - & $\Sigma(d b) \log S_{i}^{2}=763,62$ \\
\hline
\end{tabular}

Menghitung varians gabungan dari ketiga sampel:

$$
\begin{aligned}
& S^{2}=\frac{\left(n_{1} \cdot S_{1}^{2}\right)+\left(n_{2} \cdot S_{2}^{2}\right)+\left(n_{3} \cdot S_{3}^{2}\right)}{\left(n_{1}\right)+\left(n_{2}\right)+\left(n_{3}\right)} \\
& =\frac{(143 \cdot 63,939)+(143 \cdot 63,210)+(143 \cdot 54,124)}{143+143+143} \\
& =\frac{9143,277+9039,03+7739,732}{429} \\
& =\frac{25922,039}{429}=60,424
\end{aligned}
$$

Menghitung $\log S^{2}=\log 60,424=1,7812$

Menghitung nilai $B=\left(\log S^{2}\right) \cdot \Sigma(n i-1)=1,7812$ $X 429=764,13$

Menghitung nilai $X^{2}$ hitung $=($ lon 10) $[B-\Sigma(d b)$

$\left.\log \mathrm{Si}^{2}\right]=(2,3) \times[764,13-763,62]$

$=(2,3) \times[0,51]=1,173$

Bandingkan $\mathrm{X}^{2}$ hitung dengan nilai $\mathrm{X}^{2}$ tabel (chi kuadrat)

Untuk $\alpha=0,05$ dan derajat kebebasan $(\mathrm{db})=\mathrm{k}$ $-1=3-1=2$, maka $X^{2}$ tabel $=5,991$, dengan kriteria pengujian sebagai berikut:

Jika: $X^{2}$ hitung $\geq X^{2}$ tabel, tidak homogen.

Jika: $X^{2}$ hitung $\leq X^{2}$ tabel, homogen.

Ternyata $X^{2}$ hitung $<X^{2}$ tabel, atau $1,173<5,991$, maka varians-varians adalah homogen.
Kesimpulan: analisis uji korelasi dapat dilanjutkan.

\subsubsection{Uji normalitas Distribusi Data}

4.2.2.1. Uji Normalitas Gaya Belajar $\left(X_{1}\right)$

Dapat dilihat data gaya belajar berdistribusi normal dan dapat juga digunakan untuk menganalisis frekuensi, analisis hasil jawaban responden sebagai berikut:

1) Jumlah responden sebanyak 144 (N) semua tidak ada missing.

2) Untuk pertanyaan P2, P28, P29 rata-rata (mean) responden menjawab dalam nilai angka indek sebesar 3,96 dan untuk pertanyaan P9, P20, P25 responden menjawab dalam nilai angka indek masingmasing sebesar 3,97, 3,99, 3,98 atau dibulatkan dengan nilai 4 yang artinya dalam kategori setuju.

3) Untuk P29 responden menjawab 3,83 . Selanjutnya P1, P3, P6, P14, P16 rata-rata responden menjawab 3,92 dan 3,93. Ratarata hitungnya (mean) menjawab dalam kategori cukup setuju dengan nilai angka indek 3,8 dan 3,9. 
4) Median dari distribusi frekuensi rata-rata jawaban responden bernilai 4 , dari seluruh pertanyaan.

5) Mode dari distribusi frekuensi rata-rata sebesar 4.

6) Standar Deviasi, Varian, Minimum dan Maksimum jawaban responden.

Hasil analisis SPSS Versi 20 (IBM) semua pertanyaan menyatakan bahwa ratarata jawaban responden dalam kategori cukup setuju dan setuju.

Tabel 5. Chi Square Hitung Gaya Belajar

\begin{tabular}{|c|c|}
\hline \multicolumn{2}{|c|}{ Test Statistics } \\
\hline & Total \\
\hline Chi-Square & $73.778 \mathrm{a}$ \\
\hline $\mathrm{df}$ & 34 \\
\hline Asymp. Sig. & 0 \\
\hline
\end{tabular}

a 35 cells $(100.0 \%)$ have expected frequencies less than 5. The minimum expected cell frequency is 4.1 .

Analisis Hasil: Dari tabel Test Statistics Gaya Belajar $\left(\mathrm{X}_{1}\right)$ didapat Chi Square sebesar nilainya 73.778. hal ini menggambarkan bahwa distribusi frekuensi berdistribusi normal (apabila Chi Square hitung lebih kecil $<$ dari Chi Square tabel). Chi Square hit $73.778<$ Chi Square tabel 104.215.

\subsubsection{Uji Normalitas Motivasi Belajar $\left(X_{2}\right)$}

Dapat dilihat data motivasi belajar berdistribusi normal dan dapat juga digunakan untuk menganalisis frekuensi, analisis hasil jawaban responden sebagai berikut:

1) Jumlah responden sebanyak 144 (N) semua tidak ada missing.

2) Untuk pertanyaan P22, rata-rata (mean) responden menjawab dalam nilai angka indek sebesar 3,95 atau dibulatkan dengan nilai 4 yang artinya dalam kategori setuju.

3) Median dari distribusi frekuensi rata-rata jawaban responden bernilai 4 , dari seluruh pertanyaan.

4) Mode dari distribusi frekuensi rata-rata sebesar 4, dan untuk P2 mode sebesar 5 .

5) Standar Deviasi, Varian, Minimum dan Maksimum.

Hasil analisis SPSS Versi 20 (IBM) semua pertanyaan menyatakan bahwa ratarata jawaban responden dalam kategori setuju.
Tabel 6. Chi Square Hitung

\begin{tabular}{|l|l|}
\hline Test Statistics & Total \\
\hline Chi-Square & $64.542^{\mathrm{a}}$ \\
\hline $\mathrm{df}$ & 32 \\
\hline Asymp. Sig. & .001 \\
\hline
\end{tabular}

a. 33 cells (100.0\%) have expected frequencies less than

5 . The minimum expected cell frequency is 4.4 .

Analisis Hasil: Dari tabel Test Statistics didapat Chi Square sebesar nilainya 64.542. hal ini menggambarkan bahwa distribusi frekuensi berdistribusi normal (apabila Chi

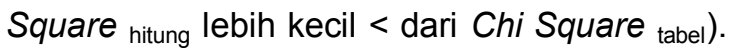
Chi Square ${ }_{\text {hit }} 65.542<$ Chi Square tabel 91.952.

\subsubsection{Uji Normalitas Hasil Belajar (Y)}

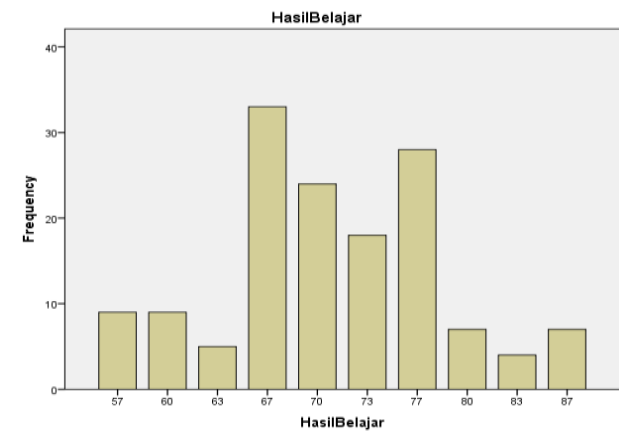

Gambar 7. Analisis Frekuensi Hasil Belajar (Y)

Tabel 7. Analisis Nilai Frekuensi Hasil Belajar

\begin{tabular}{|c|c|c|}
\hline \multicolumn{3}{|c|}{ Statistics } \\
\hline $\mathrm{N}$ & Valid & 144 \\
\hline & Missing & 0 \\
\hline Mean & & 71.04 \\
\hline Median & & 70 \\
\hline Mode & & 67 \\
\hline
\end{tabular}

Dari tabel di atas dapat dilihat data gaya belajar berdistribusi normal dan dapat digunakan menganalisis frekuensi, analisis hasil jawaban responden sebagai berikut:

1) Jumlah responden sebanyak 144 (N) semua tidak ada missing.

2) Rata-rata (mean) responden mendapatkan nilai mata pelajaran kewirausahaan 71,04 .

3) Median dari distribusi frekuensi rata-rata responden mendapatkan nilai mata pelajaran kewirausahaan 70 .

4) Mode dari distribusi frekuensi rata-rata dengan nilai 67.

5) Standar Deviasi, Varian, Minimum dan Maksimum jawaban responden lihat tabel berikut ini: 
Tabel 8. Analisis Nilai Frekuensi Distribusi

\begin{tabular}{|c|c|}
\hline Std. Deviation & 7.357 \\
\hline Variance & 54.124 \\
\hline Minimum & 57 \\
\hline Maximum & 87 \\
\hline Sum & 10230 \\
\hline
\end{tabular}

Hasil analisis SPSS Versi 20 (IBM) semua pertanyaan menyatakan bahwa rata-rata nilai responden siswa kelas XI di SMK Negeri 1 Bogor nilai minimum 57 dan maksimum 87.

Tabel 9. Chi Square Hitung

\begin{tabular}{|c|c|}
\hline Test Statistics & Hasil Belajar \\
\hline Chi-Square & $69.472^{\circ}$ \\
\hline $\mathrm{df}$ & 9 \\
\hline Asymp. Sig. & .000 \\
\hline
\end{tabular}

Dari tabel Test Statistics didapat Chi Square sebesar nilainya 69.472. hal ini menggambarkan bahwa distribusi frekuensi berdistribusi normal (apabila Chi Square hitung lebih kecil < dari Chi Square tabel). Chi Square hit $69.472<$ Chi Square tabel 91.952.

\subsubsection{Uji Linieritas Regresi}

Data dianalisis dengan menggunakan SPSS Versi 20 (IBM) atau Statistic Product and Service Solution merupakan perangkat (software statistik) dalam memecahkan analisis statistik.

Tabel 10. Case Processing Summary Gaya Belajar $\left(\mathrm{X}_{1}\right)$

\begin{tabular}{|l|l|l|l|}
\hline & & $\mathrm{N}$ & $\%$ \\
\hline Cases & Valid & 144 & 100 \\
\hline & Excluded $^{\mathrm{a}}$ & 0 & 0 \\
\hline & Total & 144 & 100 \\
\hline
\end{tabular}

Tabel 11. Reliability Statistics Gaya Belajar $\left(\mathrm{X}_{1}\right)$

\begin{tabular}{|l|l|}
\hline Cronbach's Alpha & N of Items \\
\hline 0.88 & 30 \\
\hline
\end{tabular}

Hasil analisis reliabilitas dengan model Cronbach's Alpha menggambarkan bahwa jawaban responden adalah akurat dengan nilai 0,88 . Untuk Cronbach's Alpha akan dinyatakan layak jika batasnya adalah 0,60. Analisis Cronbach's Alpha menggambarkan secara jelas jawaban responden yang akurat, dengan menganalisis item total statistic yaitu analisis corrected item total correlation. Apabila didapat $r$ nitung lebih besar dari $r$ tabel maka jawaban responden dinyatakan layak, dari jawaban responden yang $r$ hitung lebih kecil dari $r$ tabel adalah jawaban dari pertanyaan dengan $\mathrm{N}=144$ sebesar 0,159 taraf signifikan $5 \%$. Hasil C Alpha menyatakan bahwa responden pada umumnya akurat atau handal dalam penilaiannya.

Tabel 12. Case Processing Summary Motivasi Belajar $\left(\mathrm{X}_{2}\right)$

\begin{tabular}{|c|c|c|c|}
\hline & & $\mathrm{N}$ & $\%$ \\
\hline \multirow[t]{3}{*}{ Cases } & Valid & 144 & 100 \\
\hline & Excludeda & 0 & 0 \\
\hline & Total & 144 & 100 \\
\hline
\end{tabular}

Tabel 13. Reliability Statistics Motivasi Belajar

\begin{tabular}{|l|l|}
\hline Cronbach's Alpha & N of Items \\
\hline 0.844 & 30 \\
\hline
\end{tabular}

Hasil analisis reliabilitas dengan model Cronbach's Alpha menggambarkan bahwa jawaban responden adalah akurat dengan nilai 0,844. Untuk Cronbach's Alpha akan dinyatakan layak jika batasnya adalah 0,60. Analisis Cronbach's Alpha dapat juga menggambarkan secara jelas jawaban responden yang akurat, dengan menganalisis item total statistic yaitu analisis corrected item total correlation. Apabila didapat $r$ hitung lebih besar dari $r$ tabel maka jawaban responden tersebut dinyatakan layak, dari jawaban responden tersebut yang $r_{\text {hitung }}$ lebih kecil dari $r$ tabel adalah jawaban dari pertanyaan dengan $\mathrm{N}=144$ sebesar 0,159 taraf signifikan $5 \%$. Hasil C Alpha menyatakan bahwa responden pada umumnya akurat atau handal dalam penilaiannya.

\subsection{Pengujian Hipotesis}

Hipotesis yang diajukan perlu dilakukan uji hipotesis agar mendapatkan hasil penelitian yang sempurna. Pengujian hipotesis dilakukan untuk mengetahui ada tidaknya hubungan Gaya Belajar dan Motivasi Belajar dengan Hasil Belajar, sebagai berikut: 


\subsubsection{Pengujian hipotesis hubungan gaya belajar dengan hasil belajar}

Tabel 14. Descriptive Statistics

\begin{tabular}{|l|r|r|c|}
\hline & Mean & Std. Deviation & $\mathrm{N}$ \\
\hline Gaya Belajar & 121.36 & 7.996 & 144 \\
\hline Hasil Belajar & 71.04 & 7.357 & 144 \\
\hline
\end{tabular}

Hasil analisis tabel descriptive statistics menampilkan rata-rata hitung (mean) dari distribusi gaya belajar 121,36 dan hasil belajar rata-rata hitung (mean) sebesar 71,04. Hal ini menunjukkan bahwa jawaban responden dalam kategori kuat.

Tabel 15. Correlations

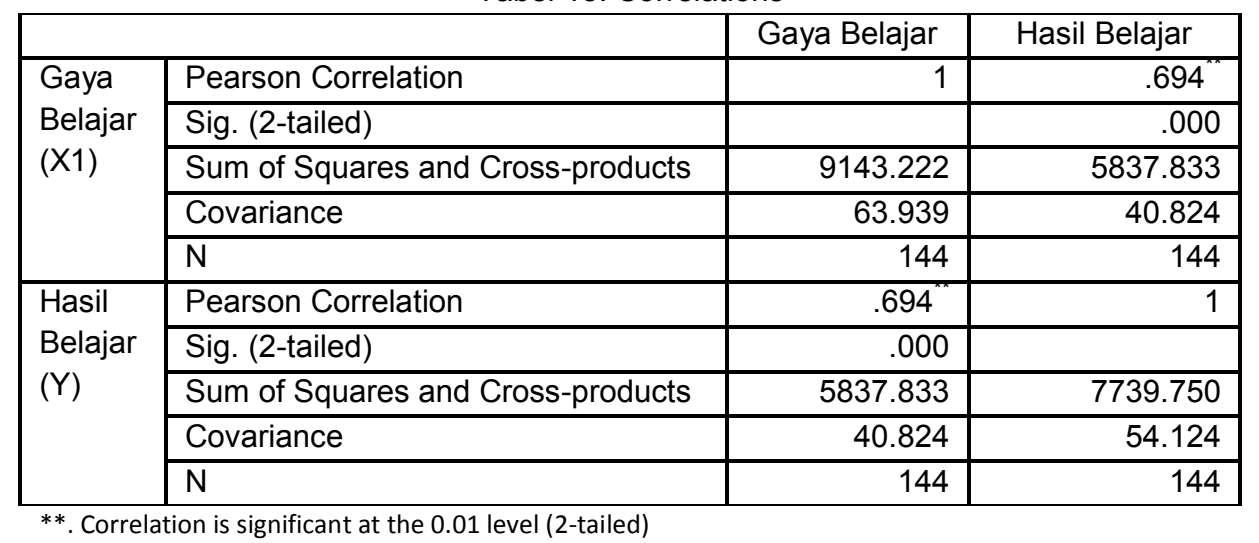

Hasil perhitungan hubungan gaya belajar dengan hasil belajar kuat, dengan nilai masing-masing sebesar 0,694, $r$ tabel $N 144=$ 0,159 , berarti $r_{\text {hitung }}>r_{\text {tabel}}$. Untuk itu dapat dinyatakan bahwa terdapat hubungan gaya belajar terhadap hasil belajar.

Tabel 16. Model Summary ${ }^{\mathrm{b}}$

\begin{tabular}{|c|c|r|r|r|r|}
\hline Model & $\mathrm{R}$ & R Square & Adjusted R Square & Std. Error of the Estimate & Durbin-Watson \\
\hline 1 & $.694^{\mathrm{a}}$ & .482 & .478 & 5.316 & 2.536 \\
\hline
\end{tabular}

a. Predictors: (Constant), Gaya Belajar

b. Dependent Variable: Hasil Belajar

Analisis Tabel Model Summary. Hasil dari tabel di atas menggambarkan nilai hubungan gaya belajar dengan hasil belajar dengan angka (square) $r^{2}=0,482$ atau sebesar $48,2 \%$, angka tersebut menunjukkan bahwa hubungan variabel gaya belajar dengan hasil belajar dinyatakan kuat, sisanya $51,8 \%(100-48,2 \%=51,8 \%)$ dipengaruhi hubungan keeratannya variabel lain.

Tabel 17. ANOVA ${ }^{a}$

\begin{tabular}{|c|c|c|c|c|c|c|}
\hline \multicolumn{2}{|c|}{ Model } & Sum of Squares & df & Mean Square & $\mathrm{F}$ & Sig. \\
\hline \multirow{3}{*}{1} & Regression & 3727.384 & 1 & 3727.384 & 131.914 & $.000^{\circ}$ \\
\cline { 2 - 8 } & Residual & 4012.366 & 142 & 28.256 & & \\
\cline { 2 - 8 } & Total & 7739.750 & 143 & & & \\
\hline
\end{tabular}

a. Dependent Variable: Hasil Belajar

b. Predictors: (Constant), GayaBelajar

Hasil analisis tabel Anova di atas $\mathrm{F}$ hitung $=131,914$ dan $F$ tabel dengan selang kepercayaan $\alpha=0,05, F_{\text {tabel }}=3,91$. Menguji dengan membandingkan $\mathrm{F}$ hitung dengan $\mathrm{F}$ tabel, hasil analisis ( $F$ tabel $3,91<F$ hitung $=131,914$ ) maka analisis regresi layak untuk dianalisis. 
Tabel 18. Coefficients ${ }^{\mathrm{a}}$

\begin{tabular}{|c|c|c|c|c|c|c|}
\hline \multicolumn{2}{|c|}{ Model } & \multicolumn{2}{|c|}{ Unstandardized Coefficients } & Standardized Coefficients & \multirow{2}{*}{$\mathrm{t}$} & \multirow{2}{*}{ Sig. } \\
\cline { 2 - 7 } & B & Std. Error & Beta & & \\
\hline 1 & (Constant) & -6.446 & 6.761 & & -.953 & .342 \\
\cline { 2 - 7 } & Gaya Belajar & .638 & .056 & .694 & 11.485 & .000 \\
\hline
\end{tabular}

a. Dependent Variable: HasilBelajar

Analisis tabel koefisien ini menggambarkan tingkat signifikan antara variabel bebas dengan variabel terikat. Untuk menentukan signifikan atau tidak $t$ hitung dengan menentukan hipotesis:

$\mathrm{H}_{\mathrm{o}}$ : Tidak ada hubungan gaya belajar dengan hasil belajar

$\mathrm{H}_{\mathrm{i}}$ : Ada hubungan gaya belajar dengan hasil belajar
Hasil $t$ hitung gaya belajar sebesar 11,485 dengan taraf signifikan 0,000 , menganalisis $t$ tabel, dengan taraf signifikan 0,05 dk $=144$ maka t tabel sebesar 1,976 (11,485 > 1,976) berarti $\mathrm{H}_{\mathrm{o}}$ di tolak dan $\mathrm{H}_{\mathrm{i}}$ di terima, untuk itu ada hubungan gaya belajar dengan hasil belajar.

\subsubsection{Pengujian hipotesis hubungan motivasi belajar dengan hasil belajar}

Tabel 19. Descriptive Statistics

\begin{tabular}{|l|r|r|c|}
\hline & \multicolumn{1}{|c|}{ Mean } & Std. Deviation & $\mathrm{N}$ \\
\hline Motivasi Belajar $(\mathrm{X} 2)$ & 125.99 & 7.950 & 144 \\
\hline Hasil Belajar $(\mathrm{Y})$ & 71.04 & 7.357 & 144 \\
\hline
\end{tabular}

Hasil analisis tabel descriptive statistics menampilkan rata-rata hitung (mean) dari distribusi motivasi belajar 125,99 dan hasil belajar rata-rata hitung (mean) sebesar 71,04. Hal ini menunjukkan bahwa jawaban responden dalam kategori kuat.

Tabel 20. Correlations

\begin{tabular}{|l|l|l|l|}
\hline \multicolumn{5}{|c|}{} & Motivasi Belajar & Hasil Belajar \\
\hline \multirow{5}{*}{ Motivasi Belajar (X2) } & Pearson Correlation & 1 & .635 \\
\cline { 2 - 4 } & Sig. (2-tailed) & & .000 \\
\cline { 2 - 4 } & Sum of Squares and Cross-products & 9038.993 & 5309.042 \\
\cline { 2 - 4 } & Covariance & 63.210 & 37.126 \\
\cline { 2 - 4 } & $\mathrm{N}$ & 144 & 144 \\
\hline \multirow{5}{*}{ Hasil Belajar (Y) } & Pearson Correlation & .635 & 1 \\
\cline { 2 - 4 } & Sig. (2-tailed) & .000 & \\
\cline { 2 - 4 } & Sum of Squares and Cross-products & 5309.042 & 7739.750 \\
\cline { 2 - 4 } & Covariance & 37.126 & 54.124 \\
\cline { 2 - 4 } & $\mathrm{N}$ & 144 & 144 \\
\hline
\end{tabular}

Hasil perhitungan hubungan motivasi belajar dengan hasil belajar kuat, dengan nilai masing-masing sebesar 0,635, $r$ tabel $N 144=$
0,159 , berarti $r_{\text {hitung }}>r_{\text {tabel. }}$. Untuk itu dapat dinyatakan bahwa terdapat hubungan motivasi belajar dengan hasil belajar.

Tabel 21. Model Summary ${ }^{b}$

\begin{tabular}{|c|c|r|r|r|r|}
\hline Model & $\mathrm{R}$ & $\mathrm{R}$ Square & Adjusted R Square & Std. Error of the Estimate & Durbin-Watson \\
\hline 1 & $.635^{\mathrm{a}}$ & .403 & .399 & 5.705 & 2.523 \\
\hline
\end{tabular}

a. Predictors: (Constant), Motivasi Belajar

b. Dependent Variable: Hasil Belajar

Analisis Tabel Model Summary. Hasil dari tabel di atas menggambarkan nilai hubungan motivasi belajar dengan hasil belajar dengan angka (square) $r^{2}=0,403$ atau sebesar $40,3 \%$, angka tersebut menunjukkan bahwa hubungan variabel gaya belajar dengan hasil belajar dinyatakan kuat, sisanya $59,7 \%(100-40,3 \%=59,7 \%)$ dipengaruhi hubungan keeratannya variabel lain. 
Tabel 22. ANOVA ${ }^{a}$

\begin{tabular}{|l|l|r|r|r|r|l|}
\hline \multicolumn{2}{|l|}{ Model } & Sum of Squares & \multicolumn{1}{c|}{ df } & Mean Square & F & Sig. \\
\hline \multirow{2}{*}{1} & Regression & 3118.259 & 1 & 3118.259 & 95.812 & $.000^{\circ}$ \\
\cline { 2 - 7 } & Residual & 4621.491 & 142 & 32.546 & & \\
\cline { 2 - 8 } & Total & 7739.750 & 143 & & & \\
\hline
\end{tabular}

a. Dependent Variable: Hasil Belajar

b. Predictors: (Constant), Motivasi Belajar

Hasil analisis tabel Anova di atas $\mathrm{F}_{\text {hitung }}$ $=95,812$ dan $F$ tabel dengan selang kepercayaan $\alpha=0,05, F$ tabel $=3,91$. Menguji dengan membandingkan $\mathrm{F}_{\text {hitung }}$ dengan $\mathrm{F}$ tabel, hasil analisis $\left(F_{\text {tabel }} 3,91<F\right.$ hitung $\left.=95,812\right)$ maka analisis regresi dinyatakan layak dianalisis.

Tabel 23. Coefficients ${ }^{a}$

\begin{tabular}{|c|c|c|c|c|c|c|}
\hline \multirow{2}{*}{\multicolumn{2}{|c|}{ Model }} & \multicolumn{2}{|c|}{ Unstandardized Coefficients } & Standardized Coefficients & \multirow{2}{*}{$t$} & \multirow{2}{*}{ Sig. } \\
\hline & & $B$ & Std. Error & Beta & & \\
\hline \multirow[t]{2}{*}{1} & (Constant) & -2.960 & 7.575 & & -.391 & .697 \\
\hline & $\begin{array}{l}\text { Motivasi } \\
\text { Belajar }\end{array}$ & .587 & .060 & .635 & 9.788 & .000 \\
\hline
\end{tabular}

a. Dependent Variable: HasilBelajar

Analisis tabel koefisien ini menggambarkan tingkat signifikan antara variabel bebas dengan variabel terikat. Untuk menentukan signifikan atau tidak $t$ hitung dengan menentukan hipotesis:

$\mathrm{H}_{\mathrm{o}}$ : Tidak ada hubungan motivasi belajar dengan hasil belajar

$\mathrm{H}_{\mathrm{i}}$ : Ada hubungan motivasi belajar dengan hasil belajar

Hasil $t$ hitung motivasi belajar sebesar 9,788 dengan taraf signifikan 0,000, menganalisis $\mathrm{t}$ tabel, dengan taraf signifikan $0,05 \mathrm{dk}=144$ maka $t_{\text {tabel }}$ sebesar 1,976 $(9,788$
$>1,976$ ) berarti $\mathrm{H}_{\circ}$ di tolak dan $\mathrm{H}_{\mathrm{i}}$ di terima, untuk itu ada hubungan motivasi belajar dengan hasil belajar.

4.3.3. Pengujian hipotesis secara bersamasama hubungan gaya belajar $\left(X_{1}\right)$ dan motivasi belajar $\left(X_{2}\right)$ dengan hasil belajar (Y)

Data dianalisis dengan menggunakan SPSS 20 (IBM) atau Statistic Product and Service Solution merupakan perangkat (software statistik) dalam memecahkan analisis statistik.

Tabel 24. Descriptive Statistics

\begin{tabular}{|c|c|c|c|}
\hline & Mean & Std. Deviation & $\mathrm{N}$ \\
\hline Gaya Belajar & 121.36 & 7.996 & 144 \\
\hline Motivasi Belajar & 125.99 & 7.95 & 144 \\
\hline Hasil Belajar & 71.04 & 7.357 & 144 \\
\hline
\end{tabular}

Hasil analisis tabel descriptive statistics menampilkan rata-rata hitung (mean) dari distribusi gaya belajar 121,36 dan motivasi belajar 125,99 dengan hasil belajar rata-rata hitung (mean) sebesar 71,04. Hal ini menunjukkan bahwa jawaban responden dalam kategori kuat.

Tabel 25. Model Summary ${ }^{b}$

\begin{tabular}{|c|c|c|c|c|c|}
\hline Model & $\mathrm{R}$ & $\mathrm{R}$ Square & Adjusted R Square & Std. Error of the Estimate & Durbin-Watson \\
\hline 1 & $.736^{\mathrm{a}}$ & 0.541 & 0.535 & 5.017 & 2.6 \\
\hline
\end{tabular}

b Dependent Variable: Hasil Belajar (Y)

Analisis Tabel Model Summary. Hasil dari tabel di atas menggambarkan nilai hubungan gaya belajar dan motivasi belajar dengan hasil belajar dengan angka (square) $r^{2}$
$=0,736$ atau sebesar $73,6 \%$, angka tersebut menunjukkan bahwa hubungan variabel gaya belajar dan motivasi belajar dengan hasil belajar dinyatakan kuat, sisanya $26,4 \%$ (100 - 
$73,6 \%=26,4 \%$ ) dipengaruhi hubungan keeratannya variabel lain.

Tabel 26. ANOVA ${ }^{a}$

\begin{tabular}{|c|c|c|c|c|c|c|}
\hline Model & & Sum of Squares & $\mathrm{df}$ & Mean Square & $\mathrm{F}$ & Sig. \\
\hline 1 & Regression & 4190.229 & 2 & 2095.115 & 83.226 & $.000 \mathrm{~b}$ \\
\hline & Residual & 3549.521 & 141 & 25.174 & & \\
\hline & Total & 7739.75 & 143 & & & \\
\hline
\end{tabular}

a Dependent Variable: Hasil Belajar (Y)

b Predictors: (Constant), Motivasi Belajar, Gaya Belajar

Hasil analisis tabel Anova di atas $\mathrm{F}_{\text {hitung }}$ $=83,226$ dan $\mathrm{F}$ tabel dengan selang kepercayaan $\alpha=0,05$, (dk) numerator: variabel -1 , dari penelitian ini jumlah variabel ada 3 maka $3-1=2$. Sedangkan denumeratornya adalah 3 variabel maka 144 -
$3=141 . F_{\text {tabel }}=3,06$. Menguji dengan membandingkan $F$ hitung dengan $F$ tabel, hasil analisis ( $F$ tabel $3,06<F$ hitung $=83,226)$ maka analisis regresi berganda dapat dinyatakan bahwa regresi berganda ini layak untuk dianalisis.

Tabel 27. Coefficients ${ }^{a}$

\begin{tabular}{|c|c|c|c|c|c|c|c|c|}
\hline & \multirow{2}{*}{ Model } & \multicolumn{2}{|c|}{$\begin{array}{l}\text { Unstandardized } \\
\text { Coefficients }\end{array}$} & \multirow{2}{*}{$\begin{array}{c}\begin{array}{c}\text { Standardized } \\
\text { Coefficients }\end{array} \\
\text { Beta }\end{array}$} & \multirow[t]{2}{*}{$\mathrm{t}$} & \multirow{2}{*}{ Sig. } & \multicolumn{2}{|c|}{ Collinearity Statistics } \\
\hline & & $\bar{B}$ & Std. Error & & & & Tolerance & VIF \\
\hline$\overline{1}$ & (Constant) & -20.697 & 7.195 & & -2.876 & 0.005 & & \\
\hline & Gaya Belajar X1 & 0.448 & 0.069 & 0.487 & 6.526 & $\overline{0}$ & 0.583 & 1.714 \\
\hline & Motivasi Belajar X2 & 0.296 & 0.069 & 0.32 & 4.288 & $\overline{0}$ & 0.583 & 1.714 \\
\hline
\end{tabular}

a Dependent Variable: Hasil Belajar $(\mathrm{Y})$

Analisis tabel koefisien ini menggambarkan tingkat signifikan antara variabel bebas dengan variabel terikat secara parsial jika dilakukan secara bersama-sama hubungan variabel bebas terhadap variabel terikat. Untuk menentukan signifikan atau tidak $t_{\text {hitung }}$ dengan menentukan hipotesis:

$\mathrm{H}_{\mathrm{o}}$ : Tidak ada hubungan gaya belajar dengan hasil belajar

$\mathrm{H}_{\mathrm{i}}$ : Ada hubungan gaya belajar dengan hasil belajar

Hasil $t$ hitung gaya belajar sebesar 6,526 dengan taraf signifikan 0,000 , menganalisis $t$ tabel, dengan taraf signifikan 0,05 dan derajat kebebasan (dk) $\mathrm{n}=2$ maka didapat $144-2=$ 142 dari tabel didapat nilai $t$ tabel sebesar 1,976 . Nilai $t$ tabel sebesar 1,976 lebih kecil dari $\mathrm{t}_{\text {hitung }}$ maka didapat $\left(\mathrm{t}_{\text {tabel }}<\mathrm{t}\right.$ hitung $=1,976<$
6,526 ) besarnya $t$ hitung dapat dinyatakan ada hubungan gaya belajar dengan hasil belajar.

$\mathrm{H}_{\mathrm{o}}$ : Tidak ada hubungan motivasi belajar dengan hasil belajar

$\mathrm{H}_{\mathrm{i}}$ : Ada hubungan motivasi belajar dengan hasil belajar

Hasil $\mathrm{t}$ hitung motivasi belajar sebesar 4,288 dengan taraf signifikan 0,000, menganalisis $\mathrm{t}$ tabel, dengan taraf signifikan 0,05 dan derajat kebebasan $(\mathrm{dk}) \mathrm{n}=2$ maka didapat $144-2=142$ dari tabel didapat nilai $t$ tabel sebesar 1,976. Nilai $t$ tabel sebesar 1,976 lebih kecil dari $\mathrm{t}_{\text {hitung }}$ maka didapat $\left(\mathrm{t}_{\text {tabel }}<\mathrm{t}\right.$ hitung $=1,976<4,288$ ) besarnya $t$ hitung dapat dinyatakan ada hubungan motivasi belajar dengan hasil belajar.

Tabel 28. Correlations

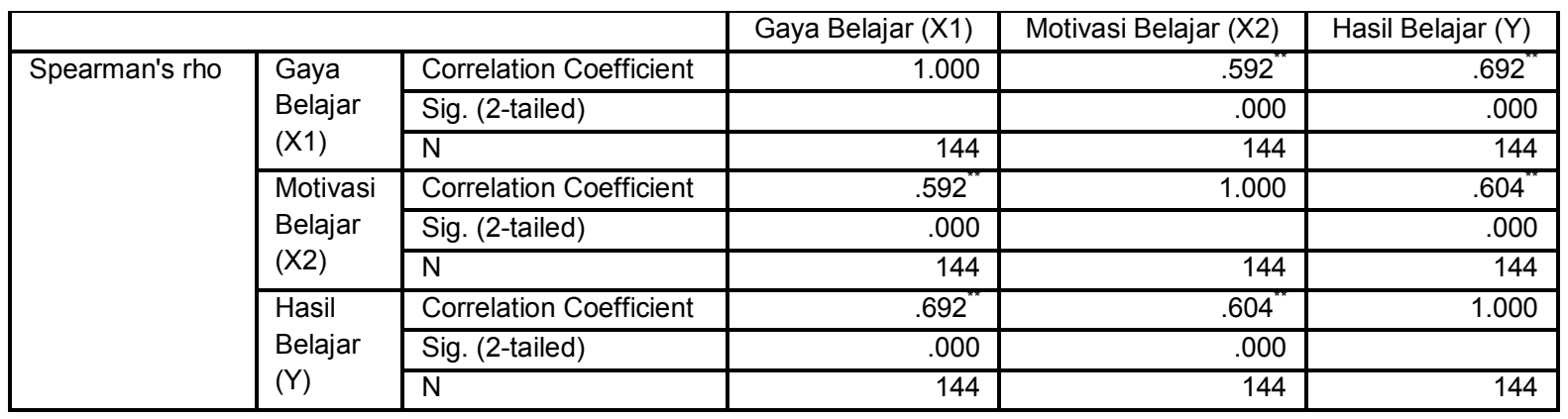


**. Correlation is significant at the 0.01 level (2-tailed).

Dari gambar tabel korelasi terlihat angka hubungan gaya belajar dan motivasi belajar sebesar $0,592^{* *}$ dengan tanda bintang 2 (dua) menunjukkan hubungan cukup kuat dan positif. Untuk menganalisa keeratan hubungan antara variabel penyebab dilakukan dengan membandingkan $r$ tabel terhadap $r_{\text {hitung }}$ maka didapat $n=144$ didapat $t$ tabel 1,976 dan $r_{\text {hitung }}$ 0,592 maka dinyatakan gaya belajar dan motivasi belajar ada hubungan yang kuat.

\subsection{Pembahasan Hasil Penelitian}

\subsubsection{Hubungan Gaya Belajar dengan Hasil Belajar}

Hasil analisis tabel descriptive statistics menampilkan rata-rata hitung (mean) dari distribusi gaya belajar 121,36 dan hasil belajar rata-rata hitung (mean) sebesar 71,04. Hal ini menunjukkan bahwa jawaban responden dalam kategori kuat.

Hasil perhitungan hubungan gaya belajar dengan hasil belajar kuat, dengan nilai masing-masing sebesar 0,694, $r$ tabel $N 144=$ 0,159 , berarti $r$ hitung $>r$ tabel. Untuk itu dapat dinyatakan bahwa terdapat hubungan gaya belajar dengan hasil belajar.

Analisis Tabel Model Summary. Hasil dari tabel di atas menggambarkan nilai hubungan gaya belajar dengan hasil belajar dengan angka (square) $r 2=0,482$ atau sebesar $48,2 \%$, angka tersebut menunjukkan bahwa hubungan variabel gaya belajar dengan hasil belajar dinyatakan kuat, sisanya $51,8 \%(100-48,2 \%=51,8 \%)$ dipengaruhi hubungan keeratannya variabel lain.

Hasil analisis tabel Anova di atas $F$ hitung $=131,914$ dan $F$ tabel dengan selang kepercayaan $\alpha=0,05, F$ tabel $=3,91$. Menguji dengan membandingkan $F$ hitung dengan $F$ tabel, hasil analisis ( $F$ tabel 3,91 $<F$ hitung = 131,914) maka analisis regresi dapat dinyatakan layak untuk dianalisis.

Analisis tabel koefisien ini menggambarkan tingkat signifikan antara variabel bebas dengan variabel terikat. Untuk menentukan signifikan atau tidak $t$ hitung dengan menentukan hipotesis:

Ho : Tidak ada hubungan gaya belajar dengan hasil belajar
$\mathrm{Hi}$ : Ada hubungan gaya belajar dengan hasil belajar

Hasil $\mathrm{t}$ hitung gaya belajar sebesar 11,485 dengan taraf signifikan 0,000, menganalisis $\mathrm{t}$ tabel, dengan taraf signifikan $0,05 \mathrm{dk}=144$ maka $\mathrm{t}$ tabel sebesar 1,976 $(11,485>1,976)$ berarti Ho di tolak dan $\mathrm{Hi}$ di terima, untuk itu ada hubungan gaya belajar dengan hasil belajar.

\subsubsection{Hubungan Motivasi Belajar dengan Hasil Belajar}

Hasil analisis tabel descriptive statistics menampilkan rata-rata hitung (mean) dari distribusi motivasi belajar 125,99 dan hasil belajar rata-rata hitung (mean) sebesar 71,04. Hal ini menunjukkan bahwa jawaban responden kategori kuat.

Hasil perhitungan hubungan motivasi belajar dengan hasil belajar kuat, dengan nilai masing-masing sebesar 0,635, $r$ tabel $\mathrm{N} 144=$ 0,159 , berarti $r$ hitung $>r$ tabel. Untuk itu dapat dinyatakan bahwa terdapat hubungan motivasi belajar terhadap hasil belajar.

Analisis Tabel Model Summary. Hasil dari tabel di atas menggambarkan nilai hubungan motivasi belajar dengan hasil belajar dengan angka (square) r2 =0,403 atau sebesar 40,3\%, angka tersebut menunjukkan bahwa hubungan variabel gaya belajar dengan hasil belajar dinyatakan kuat, sisanya $59,7 \%(100-40,3 \%=59,7 \%)$ dipengaruhi hubungan keeratannya variabel lain.

Hasil analisis tabel Anova di atas $\mathrm{F}$ hitung $=95,812$ dan $\mathrm{F}$ tabel dengan selang kepercayaan $\alpha=0,05, F$ tabel $=3,91$. Menguji dengan membandingkan $F$ hitung dengan $F$ tabel, hasil analisis ( $F$ tabel 3,91 $<F$ hitung = 95,812) maka analisis regresi dapat dinyatakan layak untuk dianalisis.

Analisis tabel koefisien ini menggambarkan tingkat signifikan antara variabel bebas dengan variabel terikat. Untuk menentukan signifikan atau tidak $t$ hitung dengan menentukan hipotesis:

Ho : Tidak ada hubungan motivasi belajar dengan hasil belajar 
$\mathrm{Hi}$ : Ada hubungan motivasi belajar dengan hasil belajar

Hasil t hitung motivasi belajar sebesar 9,788 dengan taraf signifikan 0,000, menganalisis $\mathrm{t}$ tabel, dengan taraf signifikan $0,05 \mathrm{dk}=144$ maka $\mathrm{t}$ tabel sebesar 1,976 $(9,788>1,976)$ berarti Ho di tolak dan $\mathrm{Hi}$ di terima, untuk itu ada hubungan motivasi belajar dengan hasil belajar.

\subsubsection{Hubungan Gaya Belajar dan Motivasi Belajar dengan Hasil Belajar}

Hasil analisis tabel descriptive statistics menampilkan rata-rata hitung (mean) dari distribusi gaya belajar 121,36 dan motivasi belajar 125,99 terhadap hasil belajar rata-rata hitung (mean) sebesar 71,04. Hal ini menunjukkan bahwa jawaban responden dalam kategori kuat.

Analisis Tabel Model Summary. Hasil dari tabel di atas menggambarkan nilai hubungan gaya belajar dan motivasi belajar dengan hasil belajar dengan angka (square) r2 $=0,736$ atau sebesar $73,6 \%$, angka tersebut menunjukkan bahwa hubungan variabel gaya belajar dan motivasi belajar dengan hasil belajar dinyatakan kuat, sisanya $26,4 \%$ (100 $73,6 \%=26,4 \%$ ) dipengaruhi hubungan keeratannya variabel lain.

Hasil analisis tabel Anova di atas $\mathrm{F}$ hitung $=83,226$ dan $F$ tabel dengan selang kepercayaan $\alpha=0,05$, derajat kebebasan (dk) dengan numerator: variabel -1 , dari penelitian jumlah variabel ada 3 maka $3-1=2$. Sedangkan denumeratornya adalah 3 variabel maka $144-3=141$. $F$ tabel $=3,06$. Menguji dengan membandingkan $F$ hitung dengan $F$ tabel, hasil analisis ( $F$ tabel 3,06 $<F$ hitung $=$ $83,226)$ maka analisis regresi berganda dapat dinyatakan bahwa regresi berganda ini layak untuk dianalisis.

Analisis tabel koefisien ini menggambarkan tingkat signifikan antara variabel bebas dengan variabel terikat secara parsial jika dilakukan secara bersama-sama hubungan variabel bebas dengan variabel terikat. Untuk menentukan signifikan atau tidak t hitung dengan menentukan hipotesis:

Ho : Tidak ada hubungan gaya belajar dengan hasil belajar
$\mathrm{Hi}$ : Ada hubungan gaya belajar dengan hasil belajar

Hasil $\mathrm{t}$ hitung gaya belajar sebesar 6,526 dengan taraf signifikan 0,000, menganalisis $t$ tabel, dengan taraf signifikan 0,05 dan derajat kebebasan (dk) $n=2$ maka didapat $144-2=142$ dari tabel didapat nilai $t$ tabel sebesar 1,976 . Nilai $t$ tabel sebesar 1,976 lebih kecil dari $t$ hitung maka didapat ( $t$ tabel $<\mathrm{t}$ hitung $=1,976<6,526$ ) besarnya $\mathrm{t}$ hitung dapat dinyatakan ada hubungan gaya belajar dengan hasil belajar.

Ho : Tidak ada hubungan motivasi belajar dengan hasil belajar

$\mathrm{Hi}$ : Ada hubungan motivasi belajar dengan hasil belajar

Hasil t hitung motivasi belajar sebesar 4,288 dengan taraf signifikan 0,000, menganalisis $\mathrm{t}$ tabel, dengan taraf signifikan 0,05 dan derajat kebebasan $(\mathrm{dk}) \mathrm{n}=2$ maka didapat $144-2=142$ dari tabel didapat nilai $t$ tabel sebesar 1,976. Nilai $t$ tabel sebesar 1,976 lebih kecil dari $t$ hitung maka didapat $(\mathrm{t}$ tabel $<\mathrm{t}$ hitung $=1,976<4,288$ ) besarnya $\mathrm{t}$ hitung dinyatakan ada hubungan motivasi belajar dengan hasil belajar.

Dari gambar tabel korelasi terlihat angka hubungannya sebesar $0,592^{* *}$ dengan tanda bintang dua menunjukkan hubungan cukup kuat dan positif. Untuk menganalisa keeratan hubungan variabel penyebab dilakukan membandingkan rtabel terhadap rhitung maka didapat $n=144$ didapat ttabel 1,976 dan rhitung 0,592 maka dinyatakan gaya belajar dan motivasi belajar ada hubungan yang kuat.

\section{KESIMPULAN DAN SARAN}

\subsection{Kesimpulan}

Setelah dilakukan pengumpulan dan perhitungan data, maka penulis dapat menarik kesimpulan, sebagai berikut:

1. Hubungan Gaya Belajar dengan Hasil Belajar. Hasil analisis tabel descriptive statistics menampilkan rata-rata hitung (mean) dari distribusi gaya belajar 121,36 dan hasil belajar rata-rata hitung (mean) sebesar 71,04. Hal ini menunjukkan bahwa jawaban responden dalam kategori kuat. 
Hasil perhitungan hubungan gaya belajar dengan hasil belajar kuat, dengan nilai masing-masing sebesar $0,694, r_{\text {tabel }} \mathrm{N}$ $144=0,159$, berarti $r_{\text {hitung }}>r_{\text {tabel. }}$. Untuk itu dapat dinyatakan bahwa terdapat hubungan gaya belajar dengan hasil belajar.

Analisis Tabel Model Summary. Hasil menggambarkan nilai hubungan gaya belajar dengan hasil belajar dengan angka (square) $r^{2}=0,482$ atau sebesar $48,2 \%$, angka menunjukkan bahwa hubungan variabel gaya belajar dengan hasil belajar dinyatakan kuat, sisanya 51,8\% (100 $48,2 \%=51,8 \%$ ) dipengaruhi hubungan keeratannya variabel lain.

Hasil analisis tabel Anova $\mathrm{F}_{\text {hitung }}=$ 131,914 dan $F$ tabel dengan selang kepercayaan $\alpha=0,05, F$ tabel $=3,91$. Menguji dengan membandingkan $F_{\text {hitung }}$ dengan $F_{\text {tabel }}$, hasil analisis $\left(F_{\text {tabel }} 3,91<\right.$ $\left.F_{\text {hitung }}=131,914\right)$ maka analisis regresi dapat dinyatakan layak dianalisis.

Analisis tabel koefisien menggambarkan tingkat signifikan antara variabel bebas dengan variabel terikat. Untuk menentukan signifikan atau tidak $t$ hitung dengan menentukan hipotesis:

$\mathrm{H}_{\mathrm{o}}$ : Tidak ada hubungan gaya belajar dengan hasil belajar

$\mathrm{H}_{\mathrm{i}}$ : Ada hubungan gaya belajar dengan hasil belajar

Hasil $t$ hitung gaya belajar sebesar 11,485 dengan taraf signifikan 0,000 , menganalisis $t_{\text {tabel }}$, dengan taraf signifikan $0,05 \mathrm{dk}=144$ maka $\mathrm{t}$ tabel sebesar 1,976 $(11,485>1,976)$ berarti $H_{0}$ di tolak dan $H_{i}$ di terima, untuk itu ada hubungan gaya belajar dengan hasil belajar.

2. Hubungan Motivasi Belajar dengan Hasil Belajar. Hasil analisis tabel descriptive statistics menampilkan rata-rata hitung (mean) dari distribusi motivasi belajar 125,99 dan hasil belajar rata-rata hitung (mean) sebesar 71,04 . Hal ini menunjukkan bahwa jawaban responden dalam kategori kuat.
Hasil perhitungan hubungan motivasi belajar dengan hasil belajar kuat, dengan nilai masing-masing sebesar $0,635, r_{\text {tabel }} \mathrm{N}$ $144=0,159$, berarti $r_{\text {hitung }}>r_{\text {tabel. }}$. Untuk itu dapat dinyatakan bahwa terdapat hubungan motivasi belajar dengan hasil belajar.

Analisis Tabel Model Summary. Hasil menggambarkan nilai hubungan motivasi belajar dengan hasil belajar dengan angka (square) $r^{2}=0,403$ atau sebesar 40,3\%, angka menunjukkan hubungan variabel gaya belajar dengan hasil belajar dinyatakan kuat, sisanya $59,7 \%(100-40,3 \%=59,7 \%)$ dipengaruhi hubungan keeratannya variabel lain.

Hasil analisis tabel Anova $\mathrm{F}_{\text {hitung }}=$ 95,812 dan $F$ tabel dengan selang kepercayaan $\alpha=0,05, F$ tabel $=3,91$. Menguji dengan membandingkan $F$ hitung dengan $F$ tabel, hasil analisis $\left(F_{\text {tabel }} 3,91<F\right.$ hitung $=95,812)$ maka analisis regresi dapat dinyatakan layak untuk dianalisis.

Analisis tabel koefisien menggambarkan tingkat signifikan antara variabel bebas dengan variabel terikat. Untuk menentukan signifikan atau tidak $\mathrm{t}$ hitung dengan menentukan hipotesis:

$\mathrm{H}_{\mathrm{o}}$ : Tidak ada hubungan motivasi belajar dengan hasil belajar

$\mathrm{H}_{\mathrm{i}}$ : Ada hubungan motivasi belajar dengan hasil belajar

Hasil $t_{\text {hitung }}$ motivasi belajar sebesar 9,788 dengan taraf signifikan 0,000, menganalisis $t_{\text {tabel }}$, dengan taraf signifikan $0,05 \mathrm{dk}=144$ maka $t_{\text {tabel }}$ sebesar 1,976 $(9,788>1,976)$ berarti $\mathrm{H}_{\mathrm{o}}$ di tolak dan $\mathrm{H}_{\mathrm{i}}$ di terima, untuk itu ada hubungan motivasi belajar dengan hasil belajar.

3. Hubungan Gaya Belajar dan Motivasi Belajar dengan Hasil Belajar. Hasil analisis tabel descriptive statistics menampilkan rata-rata hitung (mean) dari distribusi gaya belajar 121,36 dan motivasi belajar 125,99 terhadap hasil belajar rata-rata hitung (mean) sebesar 71,04 . Hal ini menunjukkan bahwa jawaban responden dalam kategori kuat. 
Analisis Tabel Model Summary. Hasil dari tabel di atas menggambarkan nilai hubungan gaya belajar dan motivasi belajar dengan hasil belajar dengan angka (square) $r^{2}=0,736$ atau sebesar $73,6 \%$, angka tersebut menunjukkan hubungan variabel gaya belajar dan motivasi belajar dengan hasil belajar dinyatakan kuat, sisanya $26,4 \%(100-73,6 \%=26,4 \%)$ dipengaruhi hubungan keeratannya variabel lain.

Hasil analisis tabel Anova di atas $\mathrm{F}$ hitung $=83,226$ dan $F$ tabel dengan selang kepercayaan $\alpha=0,05$, derajat kebebasan (dk) dengan numerator: variabel -1 , dari penelitian ini jumlah variabel ada 3 maka 3 $-1=2$. Sedangkan denumeratornya adalah 3 variabel maka $144-3=141$. $F_{\text {tabel }}$ $=3,06$. Menguji dengan membandingkan $F_{\text {hitung }}$ dengan $F_{\text {tabel, }}$ hasil analisis $\left(F_{\text {tabel }}\right.$ $3,06<F_{\text {hitung }}=83,226$ ) maka analisis regresi berganda dapat dinyatakan bahwa regresi berganda ini layak dianalisis.

Analisis tabel koefisien menggambarkan tingkat signifikan antara variabel bebas dengan variabel terikat secara parsial jika dilakukan secara bersama-sama hubungan variabel bebas terhadap variabel terikat. Untuk menentukan signifikan atau tidak $t_{\text {hitung }}$ dengan menentukan hipotesis:

$\mathrm{H}_{\mathrm{o}}$ : Tidak ada hubungan gaya belajar dengan hasil belajar

$\mathrm{H}_{\mathrm{i}}$ : Ada hubungan gaya belajar dengan hasil belajar

Hasil $t_{\text {hitung }}$ gaya belajar sebesar 6,526 dengan taraf signifikan 0,000, menganalisis $t_{\text {tabel }}$, dengan taraf signifikan 0,05 dan derajat kebebasan (dk) $\mathrm{n}=2$ maka didapat $144-2=142$ dari tabel didapat nilai $t_{\text {tabel }}$ sebesar 1,976 . Nilai $t_{\text {tabel }}$ sebesar 1,976 lebih kecil dari $t_{\text {hitung }}$ maka didapat $\left(\mathrm{t}_{\text {tabel }}<\mathrm{t}_{\text {hitung }}=1,976<6,526\right)$ besarnya $t_{\text {hitung dapat dinyatakan ada }}$ hubungan gaya belajar dengan hasil belajar.

$\mathrm{H}_{\mathrm{o}}$ : Tidak ada hubungan motivasi belajar dengan hasil belajar

$\mathrm{H}_{\mathrm{i}}$ : Ada hubungan motivasi belajar dengan hasil belajar
Hasil $\mathrm{t}$ hitung motivasi belajar sebesar 4,288 dengan taraf signifikan 0,000, menganalisis $t_{\text {tabel}}$, dengan taraf signifikan $0,05$ dan derajat kebebasan ( $\mathrm{dk}) \mathrm{n}=2$ maka didapat $144-2=142$ dari tabel didapat nilai $t_{\text {tabel }}$ sebesar 1,976 . Nilai $t_{\text {tabel }}$ sebesar 1,976 lebih kecil dari $t$ hitung maka didapat $(\mathrm{t}$ tabel $<\mathrm{t}$ hitung $=1,976<4,288$ ) besarnya $t$ hitung dapat dinyatakan ada hubungan motivasi belajar dengan hasil belajar.

Berdasarkan hasil perhitungan terlihat angka hubungan gaya belajar dan motivasi belajar sebesar $0,592^{* *}$ dengan tanda bintang 2 (dua) menunjukkan hubungan cukup kuat dan positif. Untuk menganalisa keeratan hubungan antara variabel penyebab dilakukan dengan membandingkan $r_{\text {tabel }}$ terhadap $r_{\text {hitung }}$ maka didapat $\mathrm{n}=144$ didapat $\mathrm{t}$ tabel 1,976 dan $r$ hitung 0,592 maka dinyatakan gaya belajar dan motivasi belajar ada hubungan yang kuat.

Simpulan:

1) Secara parsial ada hubungan kuat antara gaya belajar dengan hasil belajar sebesar 0,692 $(69,2 \%)$

2) Secara parsial ada hubungan kuat antara motivasi belajar dengan hasil belajar sebesar 0,604 $(60,4 \%)$

3) Secara bersama-sama nilai angka $r^{2}$ (square) 0,736 atau $73,6 \%$ selebihnya dipengaruhi variabel lain yang tidak dianalisis. Kompensasi dengan hasil belajar sebagai berikut dengan nilai hubungannya 0,592 maka dinyatakan ada hubung erat gaya belajar dan motivasi belajar.

\subsection{Saran}

Berdasarkan dari hasil penelitian dan kesimpulan, maka peneliti sampaikan saran sebagai bahan masukan sebagai berikut:

1. Bagi Sekolah

Diharapkan sekolah memantau efektivitas penggunaan fasilitas yang disesuaikan dengan gaya belajar visual, auditori, dan kinestetik sehingga siswa dapat menggunakan sesuai dengan gaya belajar masing-masing serta sekolah juga lebih sering memberikan motivasi belajar kepada siswa terutama siswa yang memiliki 
motivasi rendah agar dapat meningkat motivasi belajarnya terutama pada mata pelajaran kewirausahaan Kelas XI di SMK Negeri 1 Bogor.

2. Bagi Guru

a. Diharapkan pada saat mendesain pembelajaran, guru harus memperhatikan gaya belajar siswa yang berbeda-beda, baik gaya belajar visual, auditori, ataupun kinestetik pada mata pelajaran kewirausahaan, sehingga dengan disesuaikannya gaya belajar siswa yang sesuai dengan masingmasing siswa diharapkan hasil belajar kewirausahaan menjadi optimal.

b. Diharapkan lebih sering memberikan motivasi belajar kepada siswa terutama siswa yang memiliki motivasi rendah, sehingga dengan motivasi belajar yang semakin meningkat dan tinggi diharapkan hasil belajar kewirausahaan menjadi optimal.

\section{DAFTAR PUSTAKA}

Adi W. Gunawan. 2006. Genius Learning Strategy: Petunjuk Praktis untuk Menerapkan Accelerated Learning. PT Gramedia Pustaka Utama. Jakarta.

Aunurrahman. 2009. Belajar dan Pembelajaran, CV. Alfabeta, Bandung.

Benny A. Pribadi. 2009. Model Desain Sistem Pembelajaran, Dian Rakyat, Jakarta.

DePorter, Bobbi dan Hernacki, Mike. 2007. Quantum Learning: Membiasakan belajar nyaman dan menyamankan. (Penerjemah Alwiyah Abdurrahman), PT Mizan Publika (Kaifa), Bandung.

Dimyati dan Mudjiono. 2006. Belajar dan Pembelajaran, Cetakan ketiga, PT. Rineka Cipta, Jakarta.

Hackbarth, Steven. 1996. The Educational Technology Handbook: a comprehensive guide: process and products for learning, Educational Technology Publications, New Jersey.

Hamzah, B. Uno. 2009. Teori Motivasi dan Pengukurannya: Analisis di Bidang Pendidikan, Edisi 1, Cetakan kelima, Bumi Aksara, Jakarta.

Isbandi Rukminto Adi. 1994. Psikologi, Pekerjaan Sosial, dan IImu
Kesejahteraan Sosial: Dasar-dasar Pemikiran, Grafindo Persada, Jakarta. Jaali, Haji. 2009. Psikologi Pendidikan, Edisi 1, Cetakan keempat, Bumi Aksara, Jakarta.

M. Alisu Sabri. 2007. Psikologi Pendidikan Berdasarkan Kurikulum Nasional, Pedoman IImu Jaya, Jakarta.

Masyhudzulkak. 2012. Memahami Penulisan IImiah dan Metodologi Penelitian, LP2S, Bengkulu.

Muhibbin Syah. 2010. Psikologi Pendidikan: Dengan Pendekatan Baru, PT Remaja Rosdakarya, Bandung.

Nana Sudjana. 2003. Penilaian Hasil Belajar Mengajar, Remaja Rosdakarya, Jakarta

Nana Syaodih Sukmadinata. 2009. Landasan Psikologi Proses Pendidikan, PT Remaja Rosdakarya, Bandung.

S. Nasution. 2008. Berbagai Pendekatan dalam Proses Belajar dan Mengajar, Bumi Aksara, Jakarta.

Suyono dan Hariyanto. 2011. Belajar dan Pembelajaran: Teori dan Konsep Dasar, PT Remaja Rosdakarya, Bandung.

Syafaruddin dan Irwan Nasution. 2005. Manajemen Pembelajaran, Quantum Teaching, Ciputat.

Syaiful Sagala. 2011. Konsep dan Makna Pembelajaran, Alfabeta, Bandung.

UU No. 20 Tahun 2003 Tentang Sisdiknas.

Winkel. 2005. Psikologi Pengajaran, Gramedia Pustaka Tama, Jakarta.

W.S. Winkel, 1996. Psikologi Pengajaran, Grafindo, Jakarta.

Yusufhadi Miarso. 2011. Menyemai Benih Teknologi Pendidikan, Kencana, Jakarta. 